\title{
Carbon and nitrogen pools in thermokarst-affected permafrost landscapes in Arctic Siberia
}

\author{
Matthias Fuchs $^{1,2}$, Guido Grosse ${ }^{1,2}$, Jens Strauss ${ }^{1}$, Frank Günther ${ }^{1}$, Mikhail Grigoriev ${ }^{3}$, Georgy M. Maximov $^{3}$, and \\ Gustaf Hugelius ${ }^{4}$ \\ ${ }^{1}$ Alfred Wegener Institute Helmholtz Centre for Polar and Marine Research, Department of Periglacial Research, \\ 14473 Potsdam, Germany \\ ${ }^{2}$ University of Potsdam, Institute of Earth and Environmental Science, 14467 Potsdam, Germany \\ ${ }^{3}$ Melnikov Permafrost Institute, Siberian Branch of the Russian Academy of Science, 677010 Yakutsk, Russia \\ ${ }^{4}$ Department of Physical Geography, Stockholm University, 10691 Stockholm, Sweden
}

Correspondence: Matthias Fuchs (matthias.fuchs@awi.de)

Received: 4 May 2017 - Discussion started: 29 August 2017

Revised: 30 December 2017 - Accepted: 3 January 2018 - Published: 16 February 2018

\begin{abstract}
Ice-rich yedoma-dominated landscapes store considerable amounts of organic carbon $(\mathrm{C})$ and nitrogen $(\mathrm{N})$ and are vulnerable to degradation under climate warming. We investigate the $\mathrm{C}$ and $\mathrm{N}$ pools in two thermokarst-affected yedoma landscapes - on Sobo-Sise Island and on Bykovsky Peninsula in the north of eastern Siberia. Soil cores up to $3 \mathrm{~m}$ depth were collected along geomorphic gradients and analysed for organic $\mathrm{C}$ and $\mathrm{N}$ contents. A high vertical sampling density in the profiles allowed the calculation of $\mathrm{C}$ and $\mathrm{N}$ stocks for short soil column intervals and enhanced understanding of within-core parameter variability. Profile-level C and $\mathrm{N}$ stocks were scaled to the landscape level based on landform classifications from $5 \mathrm{~m}$ resolution, multispectral RapidEye satellite imagery. Mean landscape $\mathrm{C}$ and $\mathrm{N}$ storage in the first metre of soil for Sobo-Sise Island is estimated to be $20.2 \mathrm{~kg} \mathrm{C} \mathrm{m}^{-2}$ and $1.8 \mathrm{~kg} \mathrm{~N} \mathrm{~m}^{-2}$ and for Bykovsky Peninsula $25.9 \mathrm{~kg} \mathrm{C} \mathrm{m}^{-2}$ and $2.2 \mathrm{~kg} \mathrm{~N} \mathrm{~m}^{-2}$. Radiocarbon dating demonstrates the Holocene age of thermokarst basin deposits but also suggests the presence of thick Holoceneage cover layers which can reach up to $2 \mathrm{~m}$ on top of intact yedoma landforms. Reconstructed sedimentation rates of $0.10-0.57 \mathrm{~mm} \mathrm{yr}^{-1}$ suggest sustained mineral soil accumulation across all investigated landforms. Both yedoma and thermokarst landforms are characterized by limited accumulation of organic soil layers (peat).

We further estimate that an active layer deepening of about $100 \mathrm{~cm}$ will increase organic $\mathrm{C}$ availability in a seasonally thawed state in the two study areas by $\sim 5.8 \mathrm{Tg}$
\end{abstract}

(13.2 $\mathrm{kg} \mathrm{C} \mathrm{m}^{-2}$ ). Our study demonstrates the importance of increasing the number of $\mathrm{C}$ and $\mathrm{N}$ storage inventories in icerich yedoma and thermokarst environments in order to account for high variability of permafrost and thermokarst environments in pan-permafrost soil $\mathrm{C}$ and $\mathrm{N}$ pool estimates.

\section{Introduction}

Yedoma regions store large amounts of soil organic carbon (SOC) and are highly vulnerable to permafrost thaw under climate warming (Zimov et al., 2006; Strauss et al., 2013). Organic C, freeze-locked for millennia in these permafrost deposits, may become available for increased microbial activity and be released in the form of the greenhouse gases $\mathrm{CO}_{2}$ and $\mathrm{CH}_{4}$ after thaw (Gruber et al., 2004; Tarnocai, 2006; Dutta et al., 2006; Schuur et al., 2008, 2015). Carbon-rich yedoma regions therefore have the potential to contribute significantly to greenhouse gas emissions in a rapidly warming Arctic (Schneider von Deimling et al., 2015).

The term yedoma describes late Pleistocene, ice-rich, silty deposits covering vast areas in the northern permafrost regions that were not glaciated during the last ice age (Schirrmeister et al., 2011a, 2013). These deposits can reach a thickness of up to $50 \mathrm{~m}$, store large amounts of $\mathrm{C}$ and are still present today in an area of approximately $625000 \mathrm{~km}^{2}$ in the Siberian and North American permafrost region (Strauss et al., 2017). Since deglacial warming, large areas 
of the former yedoma surfaces, expanding across several million $\mathrm{km}^{2}$ of northern and eastern Siberia, Alaska, northwestern Canada, and the adjacent shelf regions, were eroded by thermokarst processes. These processes affected the landscape by permafrost thawing and ice wedge melting leading to surface lowering, lake formation, and lake drainage. Resulting landscape features include thermokarst mounds (also called baydzherakhs), thermo-erosional gullies, thermokarst lakes, and thermokarst depressions (drained thaw lake basins or alas) which now are dominant features in the yedoma terrain (Jorgenson and Shur, 2007; Veremeeva and Gubin, 2009; Kokelj and Jorgenson, 2013; Morgenstern et al., 2013; Ulrich et al., 2014).

Ice-rich yedoma and thermokarst deposits are prone to thaw after disturbances that change the surface thermal regime (e.g. from changing air temperatures, fire, or anthropogenic disturbances). Since yedoma as well as thermokarst deposits contain large, potentially vulnerable $\mathrm{C}$ pools in permafrost regions (Zimov et al., 2006; Strauss et al., 2013; Walter Anthony et al., 2014) they are of global importance for SOC accumulation, degradation, and release. Whereas degrading yedoma surfaces and thermokarst features lead to thaw-induced remobilization of organic $\mathrm{C}$, the drainage of thermokarst lakes and the following permafrost aggradation lead to SOC accumulation and stabilization (Hinkel et al., 2003; Jorgenson and Shur, 2007; Jones et al., 2012; Grosse et al., 2013). Olefeldt et al. (2016) estimated that landscapes potentially vulnerable to thermokarst contain up to $50 \%$ of the total SOC stored in the permafrost region. In the yedoma region, $60 \%$ of the $\mathrm{C}$ is stored in drained and refrozen thermokarst basins (Strauss et al., 2013). However, these estimates are based on a few data points from the yedoma region and it remains important to enhance our understanding of the $\mathrm{C}$ storage, distribution, and vulnerability in these environments with detailed landscape-scale assessments.

Several permafrost $C$ pool estimates have been carried out in different areas within the Arctic region (e.g. Michaelson et al., 1996; Kuhry et al., 2002; Ping et al., 2008; Tarnocai et al., 2009; Horwath Burnham and Sletten, 2010; Hugelius et al., 2010, 2011; Fuchs et al., 2015; Siewert et al., 2015; 2016; Palmtag et al., 2015). A synthesis for the circum-Arctic by Hugelius et al. (2014) merged a large number of data sets into the Northern Circum-polar Soil C Database (NC$\mathrm{SCD}$ ) resulting in an estimate of $1035 \pm 150 \mathrm{Pg}$ of organic $\mathrm{C}$ for $0-3 \mathrm{~m}$ for soils in the permafrost region. Several additional estimates for SOC storage in the yedoma region exist, some of which take into account slightly different components of the yedoma region. Zimov et al. (2006) calculated $450 \mathrm{Pg} \mathrm{C}$ for the $\mathrm{C}$ pool for the entire yedoma region (including both yedoma and thermokarst deposits). Walter Anthony et al. (2014) estimated the total Holocene and Pleistocene soil C pools of the yedoma region with $429 \pm 101 \mathrm{Pg} \mathrm{C}$, while Hugelius et al. (2014) calculated $181 \pm 54 \mathrm{Pg} \mathrm{C}$ for all deposits in the yedoma region below $3 \mathrm{~m}$ depth and Strauss et al. (2013) calculated $211+160 /-153 \mathrm{Pg} C$ for the entire yedoma deposits including the top $3 \mathrm{~m}$. Despite the variation in these estimates they all suggest a very large $\mathrm{C}$ pool of several hundred Pg for this region and confirm that these ice-rich deep deposits are a globally important $\mathrm{C}$ pool in the northern circumpolar permafrost region. Detailed local studies for particular parts of the yedoma region are scarce so far but suggest significant landscape-scale and interregional variation in SOC stocks that warrant further local studies and regional syntheses (Schirrmeister et al., 2011b, c; Strauss et al., 2012; Siewert et al., 2015, 2016; Shmelev et al., 2017; Webb et al., 2017).

However, the yedoma and thermokarst landscapes not only host important $\mathrm{C}$ pools but potentially store a significant amount of N. Even though there are several permafrost soil C studies, only very few report N stocks (Ping et al., 2011; Harden et al., 2012; Michaelson et al., 2013; Zubrzycki et al., 2013; Obu et al., 2017; Palmtag et al., 2016). In tundra environments, $\mathrm{N}$ often is the limiting factor for plant growth (Shaver et al., 1986; Chapin et al., 1995; Mack et al., 2004; Beermann et al., 2015). As a result, thawing permafrost does not only have the potential to release large amounts of organic $\mathrm{C}$ but can also increase the availability of $\mathrm{N}$ which may increase primary production and partly offset increased greenhouse gas emissions from permafrost soils (e.g. Keuper et al., 2012, 2017; Natali et al., 2012; Salmon et al., 2016).

A potential indicator of the potential $\mathrm{C}$ loss upon thaw and the decomposability of $\mathrm{C}$ stored in permafrost soils is the carbon to nitrogen $(\mathrm{C} / \mathrm{N})$ ratio (Schädel et al., 2014). Generally, a higher $\mathrm{C} / \mathrm{N}$ ratio suggests less degraded organic $\mathrm{C}$, while a lower $\mathrm{C} / \mathrm{N}$ ratio points towards already partly degraded $\mathrm{C}$ before incorporation into permafrost (Weiss et al., 2016). Even though the $C$ / $N$ ratio cannot be taken as a single variable to estimate the recalcitrance of the soil organic matter, it provides a first indication of the potential degradability of C stored in permafrost soils (Kuhry and Vitt, 1996; Hugelius and Kuhry, 2009; Hugelius et al., 2012).

In general, ice-rich landscapes are underrepresented in pan-Arctic permafrost $\mathrm{C}$ pool inventories and the variability of these environments is poorly accounted for. In particular, the deep $\mathrm{C}$ and $\mathrm{N}$ stocks below $1 \mathrm{~m}$ depth remain associated with high uncertainties due to low sample numbers. In addition, thermokarst areas are temporally dynamic and heterogeneous environments with characteristics that are difficult to generalize and characterize. A wide range of local case studies are needed to capture spatial variability and to improve $\mathrm{C}$ pool estimations. This study presents new data on $\mathrm{C}$ and $\mathrm{N}$ storage in two yedoma regions in the north of eastern Siberia and analyses the variability of $\mathrm{C}$ and $\mathrm{N}$ contents along landscape gradients extending from yedoma uplands into adjacent drained thaw lake basins (DTLBs) investigating whether $\mathrm{C}$ and $\mathrm{N}$ storage is significantly higher in DTLBs than in yedoma soils as proposed in regional studies by Strauss et al. (2013) or Walter Anthony et al. (2014). 


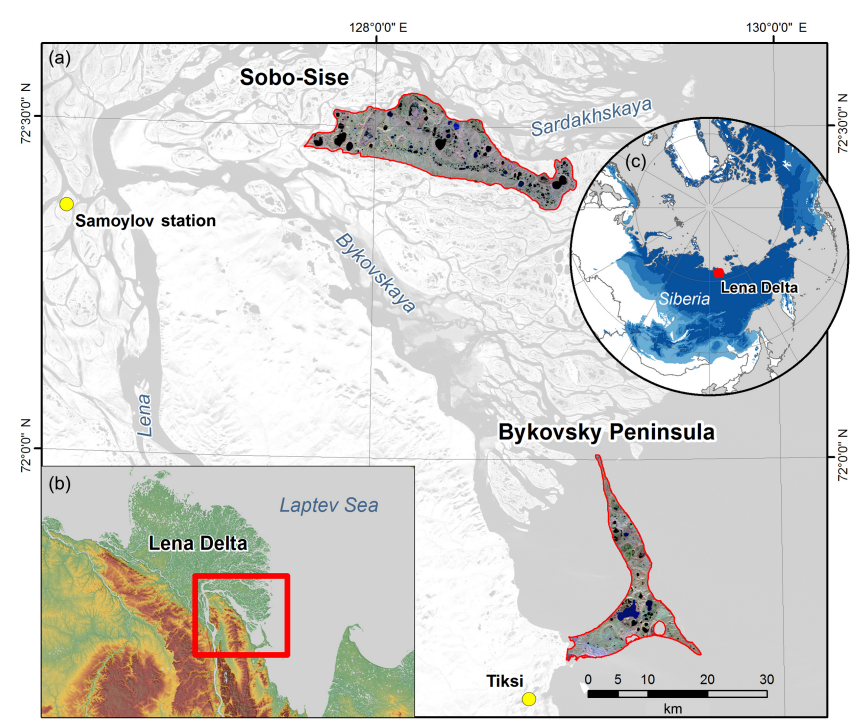

Figure 1. (a) Location of the two study areas in the Lena River delta region, Sobo-Sise Island, and Bykovsky Peninsula (Landsat 5 satellite image, acquisition date: 19 September 2009). (b) The Lena Delta region with a digital elevation model (ESA DUE-Permafrost DEM, Santoro and Strozzi, 2012), and (c) overview map including the permafrost zonation in Siberia (after Brown et al., 1997).

In this study, sediment cores up to $3 \mathrm{~m}$ depth from typical thermokarst-affected yedoma regions were analysed (1) to quantify the organic $\mathrm{C}$ and $\mathrm{N}$ variability with depth and along geomorphologic gradients in thermokarst-affected terrain; (2) to understand depositional chronologies as well as $\mathrm{C}$ accumulation rates; and (3) in combination with a satelliteimage-based terrain classification to quantify landscapescale SOC and N inventories for the study areas Bykovsky Peninsula and Sobo-Sise Island.

\section{Material and methods}

\subsection{Study area}

The two study areas are situated in the north of eastern Siberia in the Lena River delta region (Fig. 1). The first study site, Sobo-Sise Island $\left(72^{\circ} 29^{\prime} \mathrm{N}, 128^{\circ} 16^{\prime} \mathrm{E}\right)$, is a yedoma remnant within the eastern Lena Delta. These remnants are commonly referred to as the third geomorphological river delta terrace (Schwamborn et al., 2002). According to Morgenstern et al. (2011), Sobo-Sise Island accounts for almost $16 \%$ of the entire yedoma coverage in the Lena Delta. It is characterized by yedoma uplands but also features permafrost degradation landforms such as thermokarst lakes, drained thaw lake basin, and thermo-erosional gullies. SoboSise is located between two of the main channels of the Lena Delta (Sardakhskaya and Bykovskaya channels), elongated in east-west direction $(45 \mathrm{~km})$ and has an area of $336 \mathrm{~km}^{2}$. Very few studies have been conducted on the depositional characteristics of Sobo-Sise. For example, Grigoriev (1993) dated a mammoth bone from a yedoma cliff on Sobo-Sise and Grigoriev (2007) investigated the shore erosion on SoboSise's coastline. Morgenstern et al. (2011) as well as Nitze and Grosse (2016) included Sobo-Sise in regional remote sensing studies aiming at the quantification of thermokarst lakes and basins and surface landscape changes, respectively.

The second study site, Bykovsky Peninsula $\left(71^{\circ} 51^{\prime} \mathrm{N}\right.$, $129^{\circ} 19^{\prime} \mathrm{E}$ ), is similar to Sobo-Sise and also dominated by yedoma uplands that are intersected by thermokarst lakes, drained thermokarst lake basins and thermo-erosional gullies. The Bykovsky Peninsula is located to the south-east of the Lena River delta at the Laptev Sea coast and represents an erosional remnant of a late Pleistocene yedoma accumulation plain blanketing the foreland of low mountain ridges (Grosse et al., 2007). The peninsula is a narrow tongue of land with a width between 1 and $4 \mathrm{~km}$ and an area of $167 \mathrm{~km}^{2}$. In contrast to Sobo-Sise Island in the Lena Delta, the Bykovsky Peninsula is strongly affected by rapid coastal erosion from all sides and by coastal inundation, manifested in several thermokarst lagoons. Studies on the Bykovsky Peninsula focused mostly on palaeoenvironmental reconstructions using late Quaternary deposits at the exposure Mamontovy Khayata (Kunitsky, 1989; Slagoda 1991, 1993; Grigoriev, 1993; Siegert et al., 2002; Meyer et al., 2002; Schirrmeister et al., 2002a). Kholodov et al. (2006) described organic matter characteristics in Alas and yedoma deposits, Grigoriev et al. (1996) and Lantuit et al. (2011) determined coastal erosion rates on the coasts of Bykovsky Peninsula, and Grosse et al. (2005) mapped the periglacial geomorphology based on remote sensing data.

The climate of Sobo-Sise Island and Bykovksy Peninsula is continental, despite their proximity to the coast. Both sites are dominated by polar tundra climate (Peel et al., 2007). The mean annual air temperature (MAAT; period 1998-2011) on Samoylov Island (the closest weather station to Sobo-Sise, around $50 \mathrm{~km}$ to the west) is $-12.5^{\circ} \mathrm{C}$ with an approximate mean annual precipitation of 180-200 mm (including mean summer rainfall and mean snow water equivalent, period 1998-2011) (Boike et al., 2013). On Bykovsky, the climate is similar with a MAAT of $-12.9^{\circ} \mathrm{C}($ period $1933-2013)$ at the closest weather station in Tiksi (Günther et al., 2015), but a higher mean annual precipitation with around 240$260 \mathrm{~mm}$ (Grigoriev, 1993). The higher precipitation can be explained by the influence of the Laptev Sea and the mountain ridge nearby in the hinterland (Boike et al., 2013). At both study sites, permafrost is continuous and is assumed to have a thickness of about 500-650 m (Griogriev, 1993). Boike et al. (2013) reported a mean annual permafrost temperature at Samoylov Island to be $-8.6^{\circ} \mathrm{C}$ in $10.7 \mathrm{~m}$ depth.

At both study sites, the tundra vegetation is sparse and is limited by the short growing season (June to September). The vegetation composition is dominated by sedges, grasses, mosses, lichen, and sporadic dwarf shrubs (Salix species). According to Schneider et al. (2009) most of Sobo-Sise Is- 
land is classified as moist grass- and moss-dominated tundra and wet sedge- and moss-dominated tundra. In the Circum Arctic Vegetation Map (Walker et al., 2005), large parts of the Lena River delta including Sobo-Sise Island are classified as sedge, moss, dwarf shrub wetland and Bykovksy Peninsula is classified as non-tussock sedge, dwarf-shrub, moss tundra.

Following the USDA Soil Taxonomy (Soil Survey Staff, 2014) the soil types at both study sites belong to the Gelisol order with its suborders Turbels and Orthels. Only two soil profiles sampled in thermokarst deposits in this study contain thicker organic layers and can be considered as Histels. Permafrost occurs at almost all sampled sites within the first metre. Active layer thickness ranges from a minimum of $18 \mathrm{~cm}$ in thermokarst deposits to a maximum of $84 \mathrm{~cm}$ in sandy fluvial deposits with a mean of all sampled sites of $40 \mathrm{~cm}$ (median $41 \mathrm{~cm}$ ). Only at two sites in non-vegetated, sandy, temporally flooded Lena River floodplain deposits of Sobo-Sise, permafrost was not present near the surface and these soils can be classified as Entisols.

\subsection{Field work}

Soil samples were collected in August 2014 along four transects of 500 (BYK14-T3) and $600 \mathrm{~m}$ (BYK14-T2, SOB14T1, SOB14-T2) length. We chose transects to cover key geomorphologic gradients of the thermokarst-affected landscapes starting with yedoma uplands and passing through different stages of yedoma degradation (including yedoma slopes) and stages of the thermokarst lake cycle. Similar transect-based approaches were used in other regions of Siberia (Siewert et al., 2015; Palmtag et al., 2015), Canada (Hugelius et al., 2010), and Alaska (Jorgenson, 2000; Kanevskiy et al., 2014). We determined the starting points as well as the direction of each transect. To include randomness, the sampling points along the transects were then chosen at equidistant intervals in alignment with the scale of landscape features at a site. A $150 \mathrm{~m}$ distance between sampling points was chosen on the first transect (SOB14-T1) and a $100 \mathrm{~m}$ distance on the second transect (SOB14-T2). The first transect on Sobo-Sise extended from a yedoma upland into the adjacent DTLB. The second transect extended from a yedoma upland, crossing a DTLB and ending in fluvial deposits of the floodplain. Additional non-random sample points were collected on a baydzherakh (erosional remnants of polygon centres forming thermokarst hills) and two DTLBs. No cores were taken from extant thermokarst lakes or thermoerosional gullies. On Bykovsky Peninsula, transects were chosen with the same approach with a $150 \mathrm{~m}$ distance on the first transect (BYK14-T2) and $100 \mathrm{~m}$ on the second transect (BYK14-T3) between the sampling points. BYK14-T2 runs from one DTLB over a yedoma remnant covered with baydzherakhs into another adjacent DTLB. BYK14-T3 was again similar to the Sobo-Sise transects, running from the top of a yedoma upland into an adjacent DTLB.
Along the transects, soil pits were excavated down to the bottom of the active layer. A soil profile description was made and fixed-volume samples were collected with a metal cylinder of known volume. After sampling the active layer, permafrost cores and samples were collected with a SIPRE (Snow, Ice and Permafrost Research Establishment) auger barrel drill (Jon's Machine Shop, Fairbanks, USA) with a diameter of $7.62 \mathrm{~cm}\left(3^{\prime \prime}\right)$. Total sampling depths ranged from 45 to $318 \mathrm{~cm}$. As a result, at 23 sites the whole soil profile was sampled and characterized including active, transient, and permafrost layers and at five additional sites only the active layer was sampled. A permafrost core description was made and the cores were subsampled in the field at 5 to $10 \mathrm{~cm}$ intervals depending on facies horizons. The visual core description included cryostratigraphy according to French and Shur (2010) as well as a description of the lithology and plant macrofossils.

\subsection{Laboratory analysis}

In total 455 samples were processed for total carbon (TC), total nitrogen (TN), and total organic carbon (TOC). Samples were freeze-dried, homogenized by grinding prior to a measurement of 5-8 mg of the samples with a Vario EL III elemental analyser for TC and TN. Both \%C and N were measured in one run. We measured two replicates of each sample where we accept a $<5 \%$ deviation for the two measurements. The sensitivity of the elemental analyser is $<0.1 \%$. Afterwards, samples were measured for TOC $(15-100 \mathrm{mg}$, depending on the TC content) with a Vario Max C elemental analyser. Again, we allow a deviation of $<5 \%$ for the double measurements. Total inorganic carbon (TIC) is then calculated as the difference between TC and TOC. In addition, the $\mathrm{C} / \mathrm{N}$ ratio was calculated as quotient between TOC and TN contents.

Based on Hugelius et al. (2010), the (SOC) storage was calculated for each sample using Eq. (1):

$$
\begin{aligned}
\operatorname{SOC} & {\left[\mathrm{kg} \mathrm{m}^{-2}\right]=\mathrm{TOC}[\%] \times \mathrm{BD}\left[\mathrm{g} \mathrm{cm}^{-3}\right] \times(1-\mathrm{CF}) } \\
& \times \operatorname{length}[\mathrm{cm}] \times 10 .
\end{aligned}
$$

Here, TOC is the total organic $\mathrm{C}$ content derived from the elemental analysis, $\mathrm{BD}$ is the dry bulk density of the sample, $\mathrm{CF}$ is the coarse fragment fraction $(\varnothing>2 \mathrm{~mm}$ ) (which was zero because of the absence of coarse fragments in the sampled soils), and length is the actual sample length. The samplespecific SOC contents were added up to the reference depths of 0-30, 0-100, 0-200 cm. If the cores were not recovered completely, missing core intervals or missing SOC contents were interpolated between adjacent samples or from samples with the same characteristics following the field notes. The ice content in a sample is reflected in the dry bulk density and therefore included in the calculations. The SOC contents for the different reference depths, however, do not include ice wedge volumes. Ice wedge volume was included in a later step when scaling site-specific SOC stocks to the landscape 
level. Likewise the $\mathrm{N}$ storage was calculated for individual samples and for the different reference depths.

In addition, 25 subsamples from various depths of seven different sampling sites were chosen for radiocarbon dating of organic macrofossils. All samples were wet-sieved with a $2 \mu \mathrm{m}$ sieve and plant macro remains (mostly moss leaves or sedge stems) were hand-picked under a microscope. In a few cases with insufficient macro remains, bulk samples were selected. Samples were then submitted to the Radiocarbon Laboratory in Poznan, Poland, where the samples were analysed and dated with the accelerated mass spectrometer (AMS) dating method (Goslar et al., 2004). The obtained radiocarbon ages were eventually calibrated with the Calib 7.1 software to calibrated radiocarbon years before present (cal. a BP) (Stuiver and Reimer, 1993; Stuiver et al., 2017).

\subsection{Landform classification and upscaling $\mathrm{C}$ and $\mathrm{N}$ pools}

All geospatial analyses were performed in the ESRI ArcGIS 10.1 and ENVI 5.3 software. For both Sobo-Sise Island and Bykovsky Peninsula, multispectral RapidEye Images (pixel resolution $5 \mathrm{~m}$ ) in combination with high-resolution digital elevation models (DEMs) were used to classify the landscape into the dominant landscape features. For Sobo-Sise Island two scenes from the same date (27 July 2014) were orthorectified and mosaicked together to cover the entire island. To improve the data basis, the RapidEye mosaic from the 27 July 2014 was stacked with another RapidEye scene (acquisition: 30 June 2014) which covers the entire island. The same scenes (27 July and 30 June 2014 images) were also used for Bykovsky Peninsula, stacked together with an additional scene acquired on 9 September 2014 since the first scene does not cover the entire peninsula. This procedure ensures that additional landform variability from the phenological stages of the tundra vegetation at both study sites is captured entirely by at least two RapidEye scenes.

A maximum likelihood supervised classification relying on training areas was used to classify the landscape into the predominant landscape features. Identification of training areas has also been facilitated through near-simultaneous acquisition of RapidEye imagery to our field work. Training areas were chosen based on field notes and field knowledge. For Sobo-Sise Island the different RapidEye images were stacked with a DEM (pixel resolution $2 \mathrm{~m}$ ) that had been derived from photogrammetric processing of three overlapping GeoEye stereo image pairs (acquisition dates range from 27 July to 15 August 2014). For Bykovsky Peninsula, a DEM was derived from overlapping WorldView-1 and WorldView-2 stereo image pairs (acquisition period: 25 to 29 August 2015) and again combined with the 15-band deep multispectral RapidEye image stack to run the maximum likelihood classification. Adding the DEM allowed enhanced classification of yedoma uplands, since plant communities on yedoma uplands cannot be entirely distinguished from those in DTLBs based only on spectral signatures. This advantage was already demonstrated by Grosse et al. (2006) and Siewert et al. (2016), who showed that, by including a DEM, non-degraded yedoma uplands and partly degraded yedoma uplands could be better discriminated compared to image classification only.

The two landform classifications for Sobo-Sise and Bykovsky Peninsula initially included the main geomorphological units yedoma upland, partly degraded yedoma (yedoma slope), and DTLBs of different generations. However, due to the small amount of collected sampling sites in DTLBs of different generations, the landform classes of DTLBs were merged to a single-class thermokarst for the upscaling. The final landform classification used for upscaling included the following classes: yedoma uplands, degraded yedoma/yedoma slope, thermokarst, and lakes. The areas of lakes were excluded from upscaling since this study focuses on terrestrial soil C storage and no lake cores were collected.

The landform classification accuracy was based on fieldbased ground truthing points complemented with data points extracted from high-resolution imagery. The high-resolution imagery include a GeoEye (Sobo-Sise Island), WorldView2 (Bykovsky Peninsula) and aerial photography to assess the correctness of classification and overlap with the sampled field sites. For each study area, 300 randomly selected points and an additional 20 points for each landform class were manually classified and then compared with the landform classification based on the RapidEye satellite imagery.

The total SOC and N storage for Sobo-Sise and Bykovsky Peninsula was based on mean $\mathrm{C}$ stocks of the collected sampling sites for the reference depths $0-30,0-100$, and 0 $200 \mathrm{~cm}$ of each class. The mean stocks were upscaled based on the areal extent of the corresponding landform class. This approach allows a first estimate of the potential $\mathrm{C}$ and $\mathrm{N}$ storage in the study areas for the first $2 \mathrm{~m}$ of soil. Confidence intervals for the mean SOC and N landscape stocks were calculated according to Hugelius (2012). However, these confidence intervals do not include uncertainties evolving from the landform classification-based upscaling.

To avoid overestimating the $\mathrm{C}$ and $\mathrm{N}$ stocks in the upscaling, we accounted for the ice wedge volume in the landscape carbon and nitrogen calculations. Ice wedge contents for thermokarst deposits were adopted from the study of Ulrich et al. (2014) as a mean value derived from the maximum ice wedge contents from their three north-eastern Siberian study areas Ebe-Basyn-Sise, Cape Mamontov Klyk and Buor Khaya Peninsula. This resulted in a mean ice wedge volume of $9 \pm 3 \%$ (standard deviation) for thermokarst deposits which is similar to what Kanevskiy et al. (2013) found for drained lake basins in Arctic Alaska with $8 \%$. For the estimation of yedoma upland ice wedge volume, the GIS-based approach from Günther et al. (2015) was applied to SoboSise. We orthorectified the GeoEye image using our highresolution DEM in order to ensure consistent mapping in an image free of geometrical distortions. We mapped more 
Table 1. Laboratory results of soil C, N, and ground ice characteristics for the different geomorphological landform units on Sobo-Sise Island and Bykovsky Peninsula. All values are mean values \pm standard deviation. Median values for all parameters are provided in Table S2.

\begin{tabular}{lcccrrrrr}
\hline & TOC (\%) & TIC (\%) & TN (\%) & C / N (-) & $\begin{array}{r}\text { Volumetric ice } \\
\text { content* } \\
(\%)\end{array}$ & SOC $\left(\mathrm{kg} \mathrm{m}^{-3}\right)$ & $\mathrm{N}\left(\mathrm{kg} \mathrm{m}^{-3}\right)$ & $n$ \\
\hline Sobo-Sise & & & & & & & \\
Sobo-Sise yedoma upland & $4.5 \pm 3.8$ & $0.2 \pm 0.4$ & $0.3 \pm 0.1$ & $10.9 \pm 6.3$ & $61.8 \pm 14.8$ & $19.5 \pm 12.6$ & $1.7 \pm 0.9$ & 279 \\
Sobo-Sise yedoma slope & $3.1 \pm 1.8$ & $0.3 \pm 0.4$ & $0.3 \pm 0.1$ & $12.2 \pm 6.8$ & $61.5 \pm 15.0$ & $25.7 \pm 16.1$ & $2.2 \pm 1.1$ & 85 \\
Sobo-Sise thermokarst & $3.6 \pm 3.9$ & $0.1 \pm 0.4$ & $0.3 \pm 0.1$ & $10.7 \pm 2.9$ & $61.6 \pm 16.8$ & $19.6 \pm 10.0$ & $1.8 \pm 0.7$ & 33 \\
Sobo-Sise fluvial deposits & $0.8 \pm 0.7$ & $0.0 \pm 0.1$ & $0.1 \pm 0.0$ & $11.7 \pm 5.7$ & $63.1 \pm 13.7$ & $17.6 \pm 9.4$ & $1.6 \pm 0.6$ & 135 \\
\hline Bykovsky & $6.6 \pm 7.4$ & $0.7 \pm 0.4$ & $0.5 \pm 0.3$ & $11.9 \pm 6.5$ & $62.8 \pm 16.4$ & $28.9 \pm 21.2$ & $2.4 \pm 1.2$ & 176 \\
Bykovsky yedoma upland & $5.1 \pm 4.3$ & $0.6 \pm 0.4$ & $0.4 \pm 0.2$ & $10.8 \pm 3.5$ & $62.1 \pm 13.6$ & $28.1 \pm 18.4$ & $2.5 \pm 1.2$ & 80 \\
Bykovsky thermokarst & $7.9 \pm 9.0$ & $0.8 \pm 1.0$ & $0.5 \pm 0.4$ & $13.2 \pm 7.8$ & $66.4 \pm 14.3$ & $29.5 \pm 23.3$ & $2.2 \pm 1.3$ & 96 \\
\hline
\end{tabular}

* Intrasedimentary ice (excluding wedge ice volume).

than 1500 baydzherakhs that appeared in clusters on slopes around thermokarst lakes and along thermo-erosional valleys and river banks to determine the spatial dimensions of ice wedge polygons (Voronoi diagram). The largest possible circle within each polygon served as a proxy for the sediment fraction of the polygon and was put in relation to the remaining size of the polygon, representing the ice wedge fraction. This resulted in a mean ice wedge volume of $40 \pm 8 \%$ (standard deviation). For yedoma uplands on Bykovsky Peninsula an ice wedge volume of $44 \%$ was applied, which is the mean macro ground ice content on the nearby Muostakh Island (Günther et al., 2015). Both Muostakh Island and Bykovsky Peninsula have formerly been connected with each other (Grigoriev, 1993) and are now separated by a $15 \mathrm{~km}$ wide sound. For the active layer, we assumed no ice wedge volume for the calculations. Mean active layer depths for the different classes were derived from the collected soil sites. Mean active layer depths for the sampled sites are presented in the Supplement Table S1.

\section{Results}

\subsection{Sedimentological results}

Table 1 presents the laboratory results, indicating that samples from the Bykovsky Peninsula $(6.6 \% \pm 7.4)$ have a higher TOC content than samples from Sobo-Sise Island $(3.5 \% \pm 3.8)$. Being differentiated into the various landform types, samples from thermokarst on Sobo-Sise store less TOC $(3.6 \% \pm 3.9)$ than samples from yedoma uplands $(4.3 \% \pm 4.2)$ which contrasts with the Bykovsky site $(7.9 \% \pm 9.0$ for thermokarst and $5.1 \% \pm 4.3$ for yedoma upland). However, the standard deviations and therefore the variance are higher on the Bykovsky Peninsula thermokarst samples.

The total nitrogen (TN) contents show a similar pattern to the TOC values. There is less TN in the samples from
Sobo-Sise. There are, however, only very small differences in TN between the different landform types for both study areas. Whereas there is slightly more TN in yedoma upland samples than in thermokarst samples on Sobo-Sise, there is less in yedoma uplands compared to thermokarst on Bykovsky Peninsula. However, when looking at the median, the sample series (yedoma upland on Sobo, yedoma upland on Bykovsky and thermokarst on Bykovsky) tend to be similar (see Table S2 with the median values).

Volumetric ice contents are very similar for all the sampled cores. For both study sites as well as for yedoma and thermokarst the mean values range between 61 and $67 \%$. The only exceptions are the samples from fluvial sandy deposits on Sobo-Sise Island with a mean value of $45 \%$ (see Table 1). Active layer samples were excluded from this analysis.

$\mathrm{C} / \mathrm{N}$ ratios also show a similar pattern across all classes, with mean $\mathrm{C} / \mathrm{N}$ ratios ranging from 10.7 to 13.2 for the different geomorphological units. However when separating $\mathrm{C} / \mathrm{N}$ ratios into active layer and permafrost layer samples, active layer samples show a higher $\mathrm{C} / \mathrm{N}$ ratio at both study sites and in all classes. Mean $\mathrm{C} / \mathrm{N}$ ratios for active layer samples (samples from cores of same landform units combined) are 15.8 for Sobo-Sise yedoma uplands, 20.1 for Sobo-Sise thermokarst, 12.5 for Bykovsky yedoma uplands, and 17.0 for Bykovsky thermokarst. For permafrost samples mean $\mathrm{C} / \mathrm{N}$ ratios are 11.1 for Sobo-Sise yedoma uplands, 10.3 for Sobo-Sise thermokarst, 10.1 for Bykovsky yedoma upland and 11.7 for Bykovsky thermokarst. In all cases, active layer samples have higher $\mathrm{C} / \mathrm{N}$ ratios and there is a moderate correlation of decreasing $\mathrm{C} / \mathrm{N}$ ratio with increasing depth for three classes, and one weak correlation (Bykovsky thermokarst) of decreasing $\mathrm{C} / \mathrm{N}$ ratio with increasing depth (Fig. 2). 

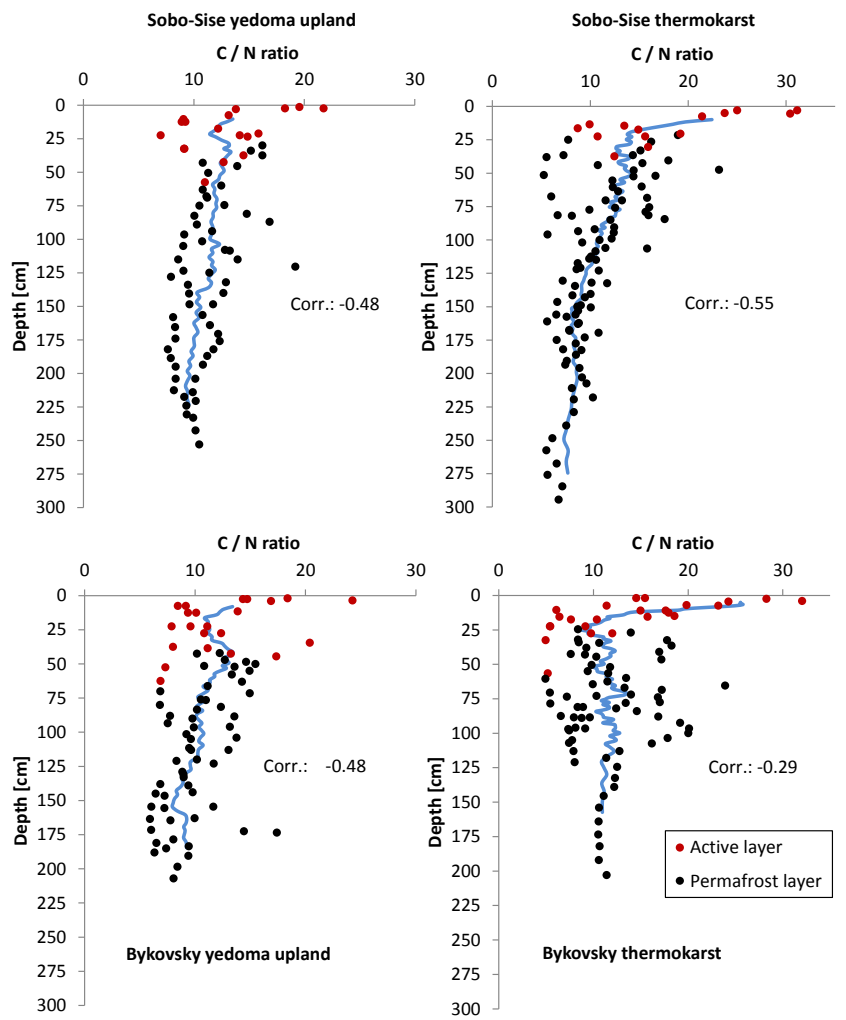

Figure 2. C / N ratio for yedoma upland and thermokarst samples on Sobo-Sise and Bykovsky Peninsula. Blue lines indicate the running mean for the entire sample set (including active layer and permafrost layer samples). The correlation (Corr.) (Pearson correlation) between $\mathrm{C} / \mathrm{N}$ ratio and depth indicates a decreasing $\mathrm{C} / \mathrm{N}$ ratio with increasing depth $(p<0.01)$.

\subsection{Sampling site SOC and N stocks}

The TOC and bulk density values were used to estimate the site SOC stocks which were averaged for the different landform types. Mean sampling site SOC stocks (excluding ice wedge volume) were higher for yedoma upland sites than for thermokarst sites for the reference depths of $0-30$ and $0-100 \mathrm{~cm}$ for both study sites (Fig. 3). SOC storages for 0$100 \mathrm{~cm}$ for Sobo-Sise are $25.3 \pm 8.0 \mathrm{~kg} \mathrm{C} \mathrm{m}^{-2}$ for yedoma upland and $19.2 \pm 5.9 \mathrm{~kg} \mathrm{C} \mathrm{m}^{-2}$ for thermokarst sites. For fluvial deposits only one profile down to $1 \mathrm{~m}$ depth was collected with an SOC stock of $11.2 \mathrm{~kg} \mathrm{C} \mathrm{m}^{-2}$. Also for 0 $200 \mathrm{~cm}$, more SOC is stored in yedoma upland soils. The findings for Bykovsky Peninsula are similar with more C stored at yedoma uplands sites in the first metre of soil than at thermokarst sites, despite the fact that a higher mean TOC content was found in the thermokarst samples. For 0$100 \mathrm{~cm}$ yedoma upland sites store $29.7 \pm 12.9 \mathrm{~kg} \mathrm{C} \mathrm{m}^{-2}$ and thermokarst sites store $23.9 \pm 9.7 \mathrm{~kg} \mathrm{C} \mathrm{m}^{-2}$. For $0-200 \mathrm{~cm}$ there is more organic $\mathrm{C}$ stored in thermokarst than in yedoma upland soils. However, this estimation is only based on one relatively C-rich core (BYK14-T3-3), since this is the only

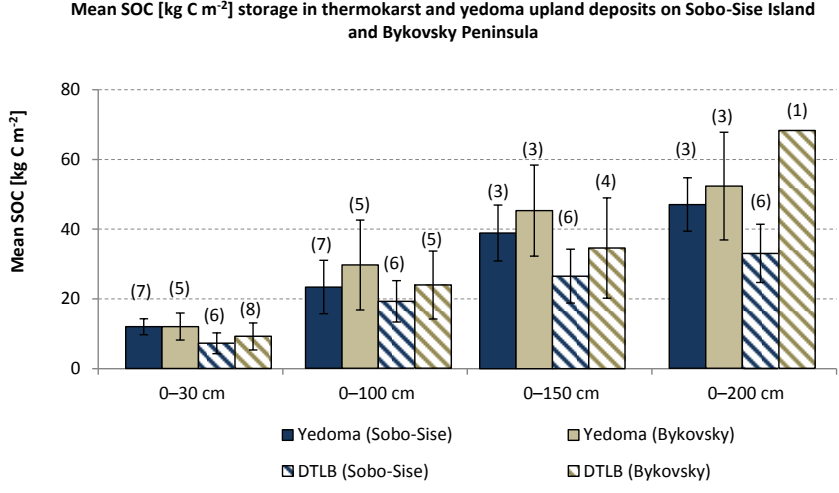

Figure 3. Comparison of mean sampling site SOC storage on SoboSise Island and on Bykovsky Peninsula. Solid bars: yedoma sites, striped bars: thermokarst sites. Black T-lines show the standard deviation, and number in brackets indicates the number of sampled sites. Profiles shorter than $200 \mathrm{~cm}$ were extrapolated to the next reference depth. When an ice wedge was reached at a collected site, this was included in the extrapolation as well, assuming no carbon for ice wedge layers. SOC data for this graph are presented in the supplementary material, Tables S1 and S4.

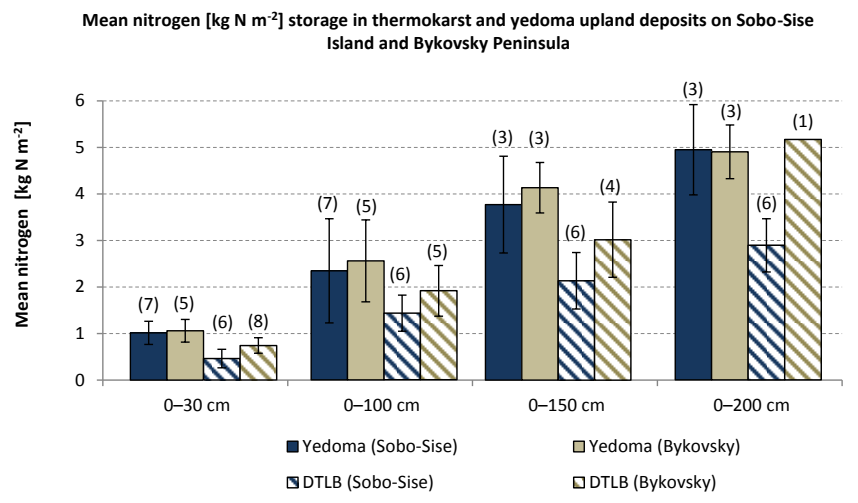

Figure 4. Mean sampling site N storage for the different geomorphic units in both study areas. Solid bars: yedoma sites, striped bars: thermokarst sites. Black T-lines show the standard deviation and number in brackets indicate the number of sampled sites. Profiles shorter than $200 \mathrm{~cm}$ were extrapolated to the next reference depth. When reaching an ice wedge in a collected site, this was included in the extrapolation as well, assuming no $\mathrm{N}$ for ice wedge layers. Soil $\mathrm{N}$ data for this graph are presented in the supplementary material, Tables S1 and S5.

core reaching a depth of $2 \mathrm{~m}$ for thermokarst on Bykovsky Peninsula. Therefore the carbon estimation of thermokarst on Bykovsky Peninsula for the soil interval 0-200 $\mathrm{cm}$ has to be interpreted carefully.

The mean sampling site soil $\mathrm{N}$ stock (excluding ice wedge volume) for yedoma upland sites on Sobo-Sise Island is $2.3 \pm 1.1 \mathrm{~kg} \mathrm{~N} \mathrm{~m}^{-2}(0-100 \mathrm{~cm})$ and for thermokarst sites it is $1.4 \pm 0.4 \mathrm{~kg} \mathrm{~N} \mathrm{~m}^{-2}$ (Fig. 4). The mean profiles of $\mathrm{N}$ storage for the first metre of soil on Bykovsky Penin- 


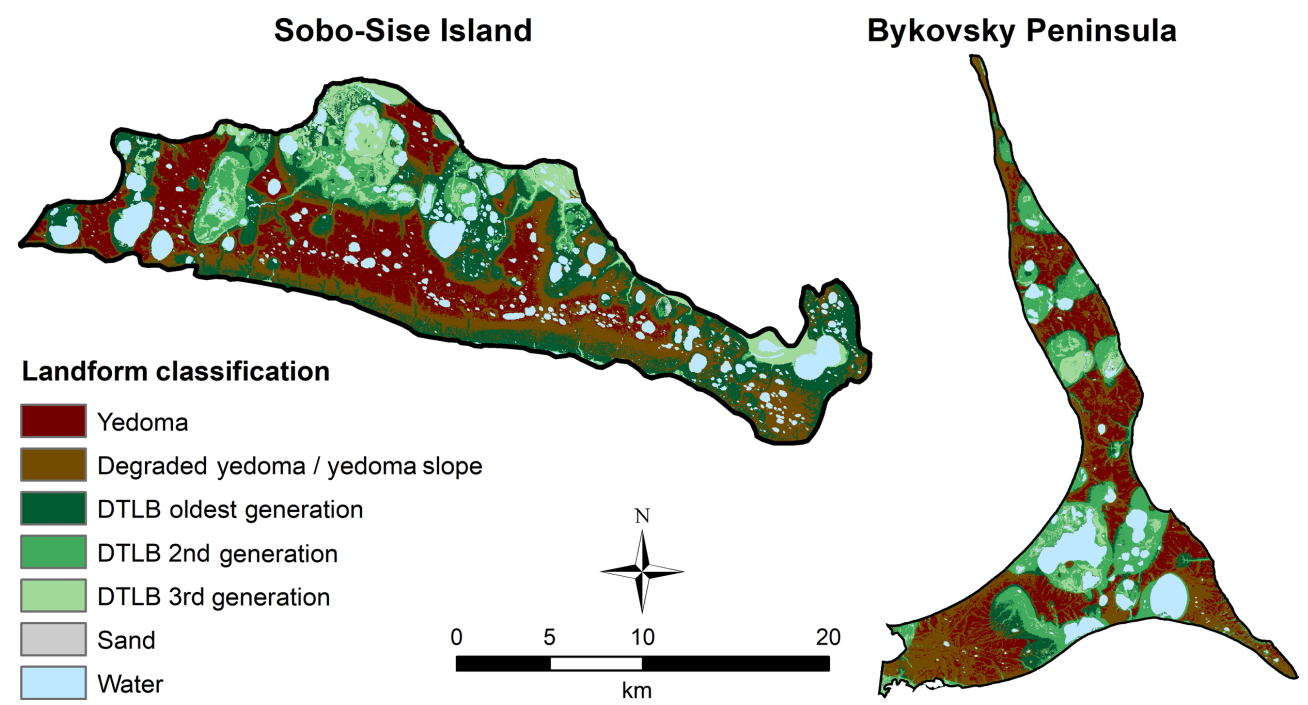

Figure 5. Landform classification of Sobo-Sise Island and Bykovsky Peninsula. For upscaling, the three classes of DTLB generations were merged into one single thermokarst class.

sula are $2.6 \mathrm{~kg} \mathrm{~N} \mathrm{~m}^{-2} \pm 0.9$ for yedoma upland sites and $1.9 \mathrm{~kg} \mathrm{~N} \mathrm{~m}^{-2} \pm 0.6$ for thermokarst sites.

\subsection{Upscaling: landscape SOC and N stocks}

The landform classification (Fig. 5) shows that 43 and $51 \%$ of the landscape on Sobo-Sise and Bykovsky, respectively, are yedoma or partly degraded yedoma. Thermokarst depressions cover approximately $43 \%$ on Sobo-Sise and $38 \%$ on Bykovsky (excluding lakes and lagoons which cover 14 and $11 \%$ of the landscapes, respectively).

Based on the landform classification and the sampling site $\mathrm{C}$ contents the total $\mathrm{C}$ storage for the two study regions was calculated. In total, $5.81 \mathrm{Tg}$ of organic $\mathrm{C}$ are stored in the first metre of soil on Sobo-Sise $\left(288 \mathrm{~km}^{2}\right)$ of which around $57 \%$ are stored within the active layer. These calculations include a landscape-wide ice wedge volume of $40 \%$ for yedoma and $9 \%$ for thermokarst, which is always applied to deposits below the active layer. This results in an average SOC storage for non-lake areas on Sobo-Sise of $20.2 \pm 2.9$ (95\% confidence interval) $\mathrm{kg} \mathrm{C} \mathrm{m}^{-2}$ for $0-100 \mathrm{~cm}$. For Bykovsky Peninsula $\left(154 \mathrm{~km}^{2}\right)$ the results are similar. In the first metre of soil, $3.98 \mathrm{Tg}$ of organic $\mathrm{C}$ are stored of which $58 \%$ are stored in the active layer, including an ice wedge volume of $44 \%$ for yedoma and $9 \%$ for thermokarst. This results in a landscape average of $25.9 \pm 9.3 \mathrm{~kg} \mathrm{C} \mathrm{m}^{-2}$ (excluding lakes) for $0-100 \mathrm{~cm}$.

Besides the organic $\mathrm{C}$, there is a considerable amount of $\mathrm{N}$ stored in the soils of Sobo-Sise Island and Bykovsky Peninsula. About $0.53 \mathrm{Tg}$ of $\mathrm{N}$ is stored on Sobo-Sise, resulting in a mean $\mathrm{N}$ storage of $1.8 \pm 0.2 \mathrm{~kg} \mathrm{~N} \mathrm{~m}^{-2}(0-100 \mathrm{~cm}$, excluding lakes). On Bykovsky, a total of $0.34 \mathrm{Tg}$ of $\mathrm{N}$ is stored in the first metre of soil. This results in a mean $\mathrm{N}$ stock of $2.2 \pm 0.5 \mathrm{~kg} \mathrm{~N} \mathrm{~m}^{-2}$ for $0-100 \mathrm{~cm}$. Mean $\mathrm{N}$ and organic $\mathrm{C}$ storage for the reference depths and the two study areas are summarized in Table 2 and the total landscape stocks are presented in Table $\mathrm{S} 3$.

\subsection{Radiocarbon dates}

In general, the radiocarbon dates (Table 3) indicate that organic matter in the first $2 \mathrm{~m}$ (and at one thermokarst site down to $3 \mathrm{~m}$ ) in both study areas is predominantly of Holocene age. Only one yedoma upland site (BYK14-T3-6B) clearly has late Pleistocene ages around $1 \mathrm{~m}$ depth. The two other dated yedoma upland sites BYK14-T2-3 and SOB14-T2-2 indicate the presence of a thick Holocene cover layer exceeding 1.67 and $2.23 \mathrm{~m}$, respectively. In general, only one age-depth inversion was found (SOB14-T2-5). At all other sites, organic matter age increased with depth.

In addition, cumulative SOC storage and radiocarbon dates were combined to calculate organic $\mathrm{C}$ accumulation rates (Table 4). Figure 6 shows the radiocarbon ages plotted against the cumulative SOC for each sampling site, indicating the $\mathrm{C}$ accumulation rates. The plots show that the $\mathrm{C}$ accumulation rate was fairly linear in all of the cores, especially when removing one age-inversion from a core (SOB14-T2-5 with $5517 \mathrm{cal}$ yr BP) and one outlier (the exceptional old date from BYK14-T2-3 with 45203 cal yr BP); however the accumulation rates vary for both the two classes thermokarst and yedoma upland soils as well as for single sampling sites. The highest mean SOC accumulation rate is found at the thermokarst site SOB14-T2-5 with $49.7 \mathrm{~g} \mathrm{C} \mathrm{m}^{-2} \mathrm{yr}^{-1}$ (and $300 \mathrm{~cm}$ of sediment accumulation), which is almost 20 times higher than SOB14-T1-5, another thermokarst site from Sobo-Sise which has a mean organic $\mathrm{C}$ accumulation rate of $2.7 \mathrm{~g} \mathrm{C} \mathrm{m}^{-2} \mathrm{yr}^{-1}$ (and $200 \mathrm{~cm}$ of sediment accumulation). This is also reflected in the different sediment accumu- 
Table 2. Mean landscape soil organic $\mathrm{C}$ and $\mathrm{N}$ storages in $\mathrm{kg} \mathrm{m}^{-2} \pm 95 \%$ confidence interval.

\begin{tabular}{lrrrrrrrr}
\hline Study site & $\begin{array}{r}\text { SOC } \\
\text { active layer }\end{array}$ & $\begin{array}{r}\text { SOC } \\
0-30 \mathrm{~cm}\end{array}$ & $\begin{array}{r}\text { SOC } \\
0-100 \mathrm{~cm}\end{array}$ & $\begin{array}{r}\text { SOC } \\
0-200 \mathrm{~cm}\end{array}$ & $\begin{array}{r}\mathrm{N} \\
\text { active layer }\end{array}$ & $\begin{array}{r}\mathrm{N} \\
0-30 \mathrm{~cm}\end{array}$ & $\begin{array}{r}\mathrm{N} \\
0-100 \mathrm{~cm}\end{array}$ & $\begin{array}{r}\mathrm{N} \\
0-200 \mathrm{~cm}\end{array}$ \\
\hline Sobo-Sise Island & $11.6 \pm 1.94$ & $9.0 \pm 1.23$ & $20.2 \pm 2.91$ & $31.3 \pm 3.56$ & $1.0 \pm 0.23$ & $0.7 \pm 0.09$ & $1.8 \pm 0.16$ & $3.0 \pm 0.23$ \\
Bykovsky Peninsula & $15.0 \pm 3.10$ & $10.8 \pm 2.25$ & $25.9 \pm 9.33$ & $48.4 \pm 9.97$ & $1.3 \pm 0.21$ & $0.9 \pm 0.13$ & $2.2 \pm 0.45$ & $4.0 \pm 0.37$ \\
\hline
\end{tabular}
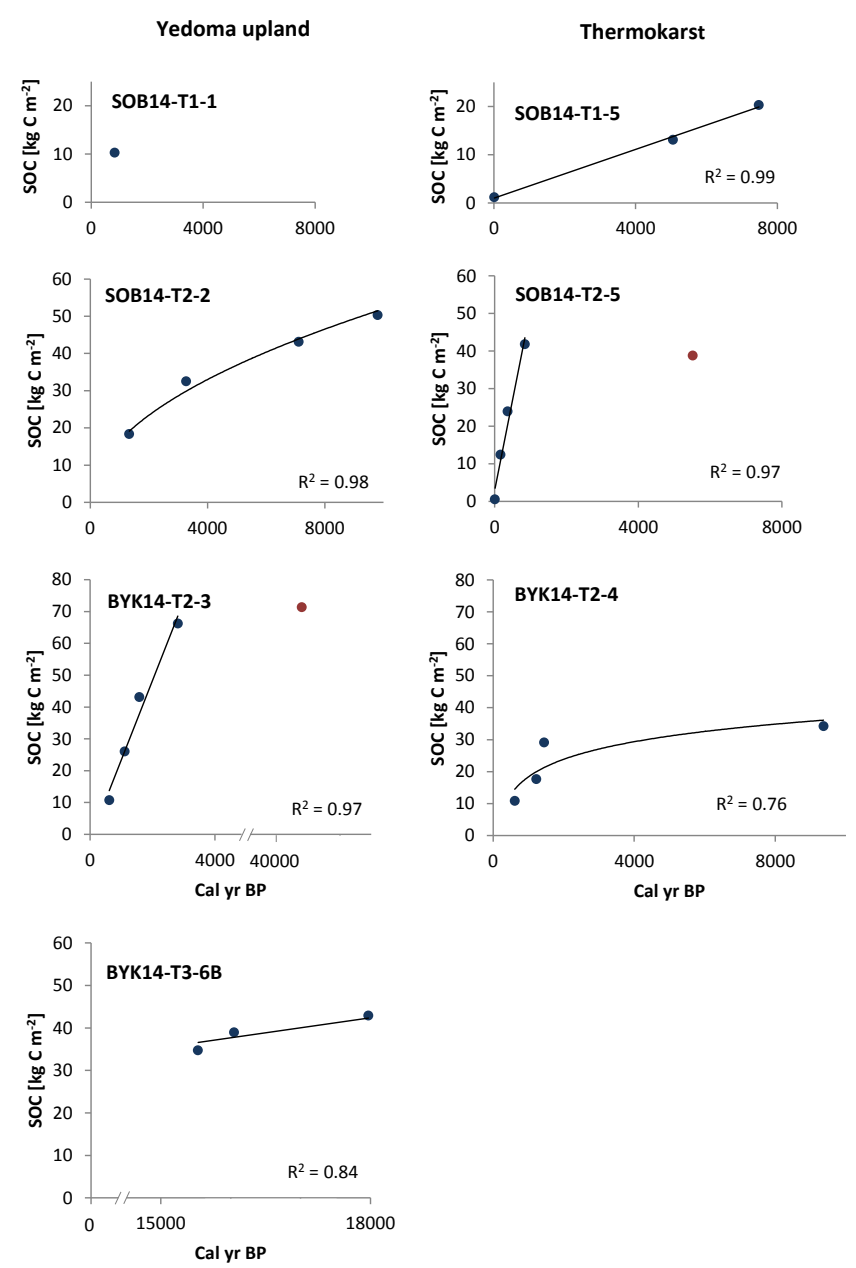

Figure 6. Relationship between cumulative SOC storage and age. Cal yr BP for radiocarbon dated samples (blue dots) for each core. Lines indicate the best fit correlation of the points excluding outliers (red dots).

lation rates (Table 4). This high variability in sediment and $\mathrm{C}$ accumulation rates reveals that even within a small area (the sites are located within $3 \mathrm{~km}$ ) high heterogeneity exists in soil forming and $\mathrm{C}$ accumulation processes.

\section{Discussion}

\subsection{Site specific soil organic $\mathrm{C}$ and $\mathrm{N}$ stock characteristics}

We found that particularly DTLBs contain less C than estimates from other studies (Strauss et al., 2013; Walter Anthony et al., 2014). However, Strauss et al. (2013) and Walter Anthony et al. (2014) also included samples from greater soil depths and partially included sites from boreal regions with higher net primary productivity, whereas our study focused on the first $3 \mathrm{~m}$ of the soils in a high-latitude tundra region. Strauss et al. (2013) did a C inventory for the entire yedoma region resulting in a SOC storage of $10+17 /-6 \mathrm{~kg} \mathrm{~m}^{-3}$ for yedoma and $31+23 /-18 \mathrm{~m}^{-3}$ for thermokarst deposits.

Thermokarst sites on Sobo-Sise Island are especially more depleted in SOC and store less $\mathrm{N}$ than the yedoma upland sites. In contrast to several previous studies investigating drained thermokarst lake basin peat accumulation in Alaska, (Bockheim et al., 2004; Hinkel et al., 2003; Jones et al., 2012) and the Kolyma region in Siberia (Walter Anthony et al., 2014), it is clear that the investigated DTLB soils in SoboSise and Bykovsky do not show signs of increased peat formation and contain only thin organic layers. Organic layer depths of the studied DTLBs on Sobo-Sise and Bykovsky Peninsula are largely less than $10 \mathrm{~cm}$ with only two sites having thicker organic-rich peaty layers at the top. This indicates that the conditions for peat accumulation in these DTLBs were not favourable. Also for yedoma upland soils, organic layers are relatively shallow $(<10 \mathrm{~cm})$. This is especially important when considering that the organic layer which insulates the ice-rich yedoma deposits from warming and thawing is only thin, rendering the yedoma in this region vulnerable to active layer deepening and permafrost degradation. Due to the lack of thick organic or peaty layers, most of the profiles were classified as mineral-dominated Orthels or Turbels. This is consistent with the argumentation in Hugelius et al. (2016) which emphasized that DTLBs do not always contain peaty $\mathrm{C}$-rich deposits (Histels).

A key reason for the rather low SOC content in DTLBs is the low primary productivity of the study sites at $\sim 72^{\circ} \mathrm{N}$ latitude. In addition, the sampled DTLBs represent only a fraction of all the basins in the study areas and may not be representative of the full range of basin ages. Previous studies from Alaska indicated that older basins contained thicker organic layers than younger basins (Hinkel 


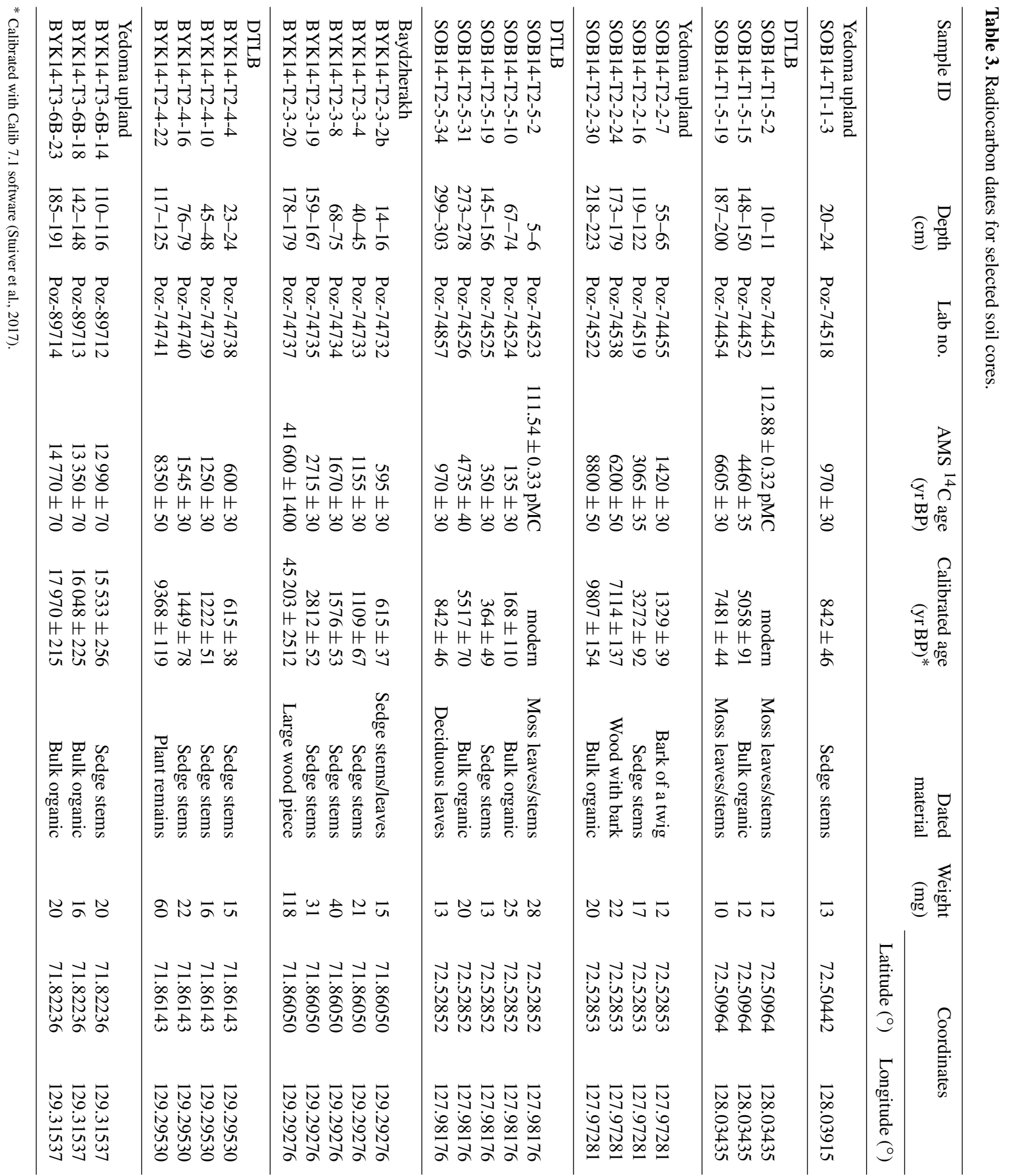


Table 4. Sediment and organic carbon accumulation rates (OC accumulation rate). Sediment accumulation rates are based on the depth of the sample and the calibrated radiocarbon date. Organic carbon accumulation rates are based on cumulative soil organic carbon (cumulative SOC) storage at a specific depth and the calibrated radiocarbon date at the corresponding depth. Mean sediment and organic carbon accumulation rates are calculated, always referring to the soil surface (depth $=0 \mathrm{~cm}$ and cumulative $\mathrm{SOC}=0 \mathrm{~kg} \mathrm{C} \mathrm{m}^{-2}$ ). Relative sediment and organic carbon accumulation rates are calculated always referring to the sample above a particular sample.

\begin{tabular}{|c|c|c|c|c|c|c|c|}
\hline Sample & $\begin{array}{r}\text { Age }^{*} \\
(\text { cal yr BP })\end{array}$ & $\begin{array}{r}\text { Cumulative SOC } \\
\qquad\left(\mathrm{kg} \mathrm{C} \mathrm{m}^{-2}\right)\end{array}$ & $\begin{array}{r}\text { Depth } \\
(\mathrm{cm})\end{array}$ & $\begin{array}{r}\text { Mean } \\
\text { sediment } \\
\text { accumulation } \\
\left(\mathrm{mm} \mathrm{yr}^{-1}\right)\end{array}$ & $\begin{array}{r}\text { Relative } \\
\text { sediment } \\
\text { accumulation } \\
\left(\mathrm{mm} \mathrm{yr}^{-1}\right)\end{array}$ & $\begin{array}{r}\text { Mean OC } \\
\text { accumulation } \\
\text { rate } \\
\left(\mathrm{g} \mathrm{C} \mathrm{m}^{-2} \mathrm{yr}^{-1}\right)\end{array}$ & $\begin{array}{r}\text { Relative OC } \\
\text { accumulation } \\
\text { rate } \\
\left(\mathrm{g} \mathrm{C} \mathrm{m}^{-2} \mathrm{yr}^{-1}\right)\end{array}$ \\
\hline SOB14-T1-1-3 & 842 & 10.29 & $19.5-23.5$ & 0.26 & 0.26 & 12.2 & 12.2 \\
\hline SOB14-T1-5-2 & modern & 1.21 & $10-11$ & $\mathrm{n} / \mathrm{a}$ & $\mathrm{n} / \mathrm{a}$ & $\mathrm{n} / \mathrm{a}$ & $\mathrm{n} / \mathrm{a}$ \\
\hline SOB14-T1-5-15 & 5058 & 13.13 & $148-150$ & 0.29 & 0.29 & 2.6 & 2.6 \\
\hline SOB14-T1-5-19 & 7481 & 20.34 & $187-200$ & 0.26 & 0.18 & 2.7 & 3.0 \\
\hline SOB14-T2-2-7 & 1329 & 18.30 & $55-65$ & 0.45 & 0.45 & 13.8 & 13.8 \\
\hline SOB14-T2-2-16 & 3272 & 32.47 & $119-122$ & 0.37 & 0.31 & 9.9 & 7.3 \\
\hline SOB14-T2-2-24 & 7113.5 & 43.13 & $173-179$ & 0.25 & 0.14 & 6.1 & 2.8 \\
\hline SOB14-T2-2-30 & 9807 & 50.31 & $218-223$ & 0.22 & 0.17 & 5.1 & 2.7 \\
\hline SOB14-T2-5-2 & modern & 0.54 & $5-6$ & $\mathrm{n} / \mathrm{a}$ & $\mathrm{n} / \mathrm{a}$ & $\mathrm{n} / \mathrm{a}$ & $\mathrm{n} / \mathrm{a}$ \\
\hline SOB14-T2-5-10 & 168 & 12.43 & $67-74$ & 4.20 & 4.20 & 74.0 & 74.0 \\
\hline SOB14-T2-5-19 & 364 & 23.97 & $145-156$ & 4.13 & 4.08 & 65.9 & 58.9 \\
\hline SOB14-T2-5-31 & 5517 & 38.78 & 273-278 & 0.50 & 0.24 & 7.0 & 2.9 \\
\hline SOB14-T2-5-34 & 842 & 41.83 & $298.5-302.5$ & 3.57 & 3.14 & 49.7 & 37.4 \\
\hline BYK14-T2-3-2b & 615 & 10.76 & $14-16$ & 0.24 & 0.24 & 17.5 & 17.5 \\
\hline BYK14-T2-3-4 & 1109 & 26.07 & $40-45$ & 0.38 & 0.56 & 23.5 & 31.0 \\
\hline BYK14-T2-3-8 & 1576 & 43.14 & $68-75$ & 0.45 & 0.62 & 27.4 & 36.6 \\
\hline BYK14-T2-3-19 & 2812 & 66.24 & $159-167$ & 0.58 & 0.74 & 23.6 & 18.7 \\
\hline BYK14-T2-3-20 & 45203 & 71.34 & $178-179$ & 0.04 & 0.004 & 1.6 & 0.1 \\
\hline BYK14-T2-4-4 & 615 & 10.87 & $23-24$ & 0.38 & 0.38 & 17.7 & 17.7 \\
\hline BYK14-T2-4-10 & 1222 & 17.63 & $45-48$ & 0.38 & 0.38 & 14.4 & 11.1 \\
\hline BYK14-T2-4-16 & 1449 & 29.10 & 76-79 & 0.53 & 1.37 & 20.1 & 50.5 \\
\hline BYK14-T2-4-22 & 9368 & 34.23 & $117-125$ & 0.13 & 0.05 & 3.7 & 0.6 \\
\hline BYK14-T3-6B-14 & 15533 & 34.69 & $110-116$ & 0.07 & 0.07 & 2.2 & 2.2 \\
\hline BYK14-T3-6B-18 & 16048 & 38.96 & $142-148$ & 0.09 & 0.62 & 2.4 & 8.3 \\
\hline BYK14-T3-6B-23 & 17970 & 42.89 & 185-191 & 0.10 & 0.22 & 2.4 & 2.0 \\
\hline
\end{tabular}

* Radiocarbon dates were calibrated with the Calib 7.1 software (Stuiver et al., 2017). n/a = not applicable.

et al., 2003; Jones et al., 2012). Other reasons may include the topographic gradient that impacts how well the DTLBs are drained and whether these basins remain waterlogged peat-forming landscapes or become dry environments that are not favourable for peat formation. Several of the studied DTLBs were eroded by the Lena River (Sobo-Sise) or the sea (Bykovsky Peninsula) and some have deeply incised drainage channels, all of which caused rather strong drainage gradients and enhanced landscape drying.

Our mean landscape SOC stocks for Sobo-Sise Island and Bykovsky Peninsula are, however, in the same range as previous studies in similar settings. For example, Siewert et al. (2016) found a mean of $19.2 \mathrm{~kg} \mathrm{C} \mathrm{m}^{-2}(0-100 \mathrm{~cm})$ in another yedoma-dominated landscape in the central Lena River delta. Zubrzycki et al. (2013) investigated the SOC character- istics of the Holocene river terrace and the active floodplain in the Lena River delta and found mean SOC stocks of 29.5 and $13.6 \mathrm{~kg} \mathrm{C} \mathrm{m}^{-2}$, respectively. The $\mathrm{C}$ storage of the active floodplain is therefore very similar to the $11.2 \mathrm{~kg} \mathrm{C} \mathrm{m}^{-2}$ for fluvial deposits in our study area. Ping et al. (2011) also investigated $\mathrm{C}$ storage along the Alaska Beaufort Sea coastline and found a normalized mean landscape storage of $38 \mathrm{~kg} \mathrm{C} \mathrm{m}^{-2}$. However, this number is based on profiles only and not on a landscape-based upscaling. Shmelev et al. (2017) investigated sites in the Kolyma yedoma region and found a $\mathrm{C}$ storage of $17.0 \pm 51.1 \mathrm{~kg} \mathrm{C} \mathrm{m}^{-3}$ (note that it is $\mathrm{kg} \mathrm{C} \mathrm{m}^{-3}$ ) for the Holocene cover layer, $16.2 \pm 31.3 \mathrm{~kg} \mathrm{C} \mathrm{m}^{-3}$ for the Alas (thermokarst) deposits and $14.0 \pm 23.5 \mathrm{~kg} \mathrm{C} \mathrm{m}^{-3}$ for yedoma deposits. These values, however, refer not only to the first $2 \mathrm{~m}$ of soil cover- 
ing Pleistocene Ice Complex deposits but to the upper $25 \mathrm{~m}$ of Yedoma Ice Complex. Also, Webb et al. (2017) investigated deep $(15 \mathrm{~m}) \mathrm{C}$ stocks in a larch-dominated yedoma area in the Kolyma River basin and found more organic C at the Alas site than at the yedoma site. Based on a landscape upscaling, Siewert et al. (2015) calculated the SOC storage for the Kytalik region, a yedoma- and thermokarstdominated tundra landscape in the Yana-Indigirka Lowland, to $25.8 \pm 9.9 \mathrm{~kg} \mathrm{C} \mathrm{m}^{-2}$ for the first metre of soils which falls in the range spanned by the Sobo-Sise Island and Bykovsky Peninsula calculations.

Aside from organic $\mathrm{C}$, a significant amount of $\mathrm{N}$ is stored in the soils of Bykovsky Peninsula and Sobo-Sise Island, almost twice as much as what has been found in the study by Zubrzycki et al. (2013) for the Holocene river terrace $\left(1.2 \mathrm{~kg} \mathrm{~m}^{-2}\right)$ and the active floodplain $\left(0.9 \mathrm{~kg} \mathrm{~m}^{-2}\right)$ of the Lena Delta. Obu et al. (2017) reported higher N storages from the western Canadian Arctic, where $3.4 \mathrm{~kg} \mathrm{~N} \mathrm{~m}^{-2}$ is stored in cryoturbated or recently disturbed type soils or sediments and Michaelson et al. (2013) calculated a mean N storage of $2.7 \mathrm{~kg} \mathrm{~m}^{-2}$ for Arctic Alaska pedons. The normalized average $\mathrm{N}$ storage from the Alaskan Beaufort Sea coast is in the same range with $1.9 \mathrm{~kg} \mathrm{~N} \mathrm{~m}^{-2}$ (Ping et al., 2011) and $\mathrm{N}$ storages from two study sites on Taymir Peninsula are also in the same range, with 1.0 and $1.3 \mathrm{~kg} \mathrm{~N} \mathrm{~m}^{-2}$ (Palmtag et al., 2016).

Even though the $\mathrm{N}$ storages are an order of magnitude lower than the organic $\mathrm{C}$ storages, a large amount of $\mathrm{N}$ is present in these soils. Since N is the limiting factor for plant growth in Arctic environments (Shaver et al., 1986; Chapin et al., 1995; Mack et al., 2004; Beermann et al., 2015), permafrost thawing will affect the $\mathrm{N}$ stocks in the soils. The $\mathrm{N}$ could partially become available to plants upon permafrost thawing. However, the role of $\mathrm{N}$ and whether it can offset an increased organic carbon release through increased plant growth needs further exploration. In a recent study, Keuper et al. (2017) found that plant-available $\mathrm{N}$ from thawing permafrost is an additional source of deep-rooting subarctic plants and can increase their biomass production. Also, Salmon et al. (2016) reported that increased N from thawed permafrost enhances plant growth and biomass, but that it might not offset $\mathrm{C}$ from deep deposits. An increase in $\mathrm{N}$ has, however, the potential to change the plant productivity and the species composition (Keuper et al., 2012). Keuper et al. (2012) show that not only dissolved plant-available $\mathrm{N}$ becomes available with permafrost thawing but also organically bound $\mathrm{N}$ can be mineralized at faster rates in thawed near permafrost soils.

However, an increase in $\mathrm{N}$ availability might both stimulate vegetation growth and increase microbial activity (Nowinski et al., 2008). Also, Koven et al. (2015) report that near-surface $\mathrm{N}$ released from thawing permafrost might reduce nutrient limitations, even though the same study shows limited importance of the deep soil $\mathrm{N}$ to offset deep $\mathrm{C}$ release. In an expert assessment Abbott et al. (2016) stated that even an increase in Arctic and boreal biomass might not offset permafrost carbon release. Since we only focused on N stocks, we cannot derive conclusions on potential plant-available $\mathrm{N}$ in the soils of Sobo-Sise Island and Bykovsky Peninsula and its effect on the primary production or $\mathrm{C}$ release. Nevertheless, this first estimation of total $\mathrm{N}$ in the soils of Sobo-Sise Island and Bykovsky Peninsula will be relevant for future climate models.

\subsection{Upscaling of $\mathrm{C}$ and $\mathrm{N}$ pools}

The total C stocks of our study sites are in the range of other permafrost $\mathrm{C}$ studies and confirm previous high $\mathrm{C}$ stock estimates from northern permafrost regions (e.g. Hugelius et al., 2014). The landform classification proved to be adequate for the upscaling. The overall accuracies for the classification are 71.5 and $71.1 \%$ for Sobo-Sise and Bykovsky, respectively. Additional field data in a greater variety of subclasses and with more diversified classification would further increase the precision of the upscaling. Nevertheless, by including a high-resolution DEM, classifying remotely sensed images into geomorphological landform types results in an accurate map of a first estimation of SOC and N stocks on the landscape level. In this context, of particular note is the areal fraction of yedoma uplands we found on Sobo-Sise Island and the Bykovsky Peninsula of 43 and $51 \%$, respectively. While this is within the range Morgenstern et al. (2011) described for the third terrace of the Lena Delta, on a larger regional level yedoma coverage is generally lower. For example Veremeeva and Glushkova (2016) calculated $16 \%$ of yedoma coverage for the entire Kolyma Lowland. However, our higher values are a combination of yedoma uplands and partly degraded yedoma slopes. Excluding areas with slopes, $19 \%$ of Sobo-Sise and $22 \%$ of Bykovsky Peninsula are covered by intact yedoma uplands not yet significantly affected by thermokarst or erosion.

For upscaling deep $\mathrm{C}$ and $\mathrm{N}$ pools, the determination of ice wedge volumes is important. In our study we assessed ice wedge volume using a combination of literature values and own values derived form a GIS-based analysis of highresolution satellite data. This analysis was based on more than 1500 mapped baydzherakhs and resulted in a mean ice wedge volume of $40 \%$ for Sobo-Sise Island with a standard deviation of $\pm 8 \%$. Conducting additional calculations with an $\pm 8 \%$ ice wedge volume for yedoma uplands and $\pm 3 \%$ for thermokarst areas would lead to a $\pm 4 \%$ higher respective lower landscape SOC stock $( \pm 5 \%$ for $\mathrm{N})$ for $0-100 \mathrm{~cm}$ and $\pm 7 \%$ of SOC and total $\mathrm{N}$ for $0-200 \mathrm{~cm}$ for Sobo-Sise Island. While these results are still in the same range, this analysis reveals the importance of assessing ice wedge volumes correctly within a landscape for SOC and N upscaling, especially for deep deposit calculations. For a more detailed upscaling and to capture the entire variability of these heterogeneous environments, additional and deeper soil cores are needed as well as a more detailed estimation of the land- 
Table 5. Potential C thaw out for different active layer deepening scenarios.

\begin{tabular}{lrrrrr}
\hline & $\begin{array}{r}\text { Active layer } \\
+10 \mathrm{~cm}\end{array}$ & $\begin{array}{r}\text { Active layer } \\
+20 \mathrm{~cm}\end{array}$ & $\begin{array}{r}\text { Active layer } \\
+50 \mathrm{~cm}\end{array}$ & $\begin{array}{r}\text { Active layer } \\
+100 \mathrm{~cm}\end{array}$ & Area \\
\hline Sobo-Sise Island & $0.45 \mathrm{Tg}$ & $0.80 \mathrm{Tg}$ & $1.62 \mathrm{Tg}$ & $3.40 \mathrm{Tg}$ & $287.7 \mathrm{~km}^{2}$ \\
Bykovsky Peninsula & $0.25 \mathrm{Tg}$ & $0.48 \mathrm{Tg}$ & $1.32 \mathrm{Tg}$ & $2.44 \mathrm{Tg}$ & $154.0 \mathrm{~km}^{2}$ \\
Total & $0.70 \mathrm{Tg}$ & $1.28 \mathrm{Tg}$ & $2.94 \mathrm{Tg}$ & $5.83 \mathrm{Tg}$ & $441.7 \mathrm{~km}^{2}$ \\
\hline
\end{tabular}

scape ice wedge contents to further improve SOC and soil $\mathrm{N}$ pool estimations.

\subsection{Sediment and organic $\mathrm{C}$ accumulation rates}

Most of the analysed soil $\mathrm{C}$ was of Holocene age. Even for yedoma upland soils, radiocarbon dates indicated a large number of Holocene ages. Hence, the yedoma uplands appear to be blanketed by Holocene cover material sometimes exceeding a thickness of $2 \mathrm{~m}$, which needs to be accounted for in carbon pool inventories, because these $2 \mathrm{~m}$ cover deposits cannot be considered as yedoma. In DTLBs, the Holocene age of soil $\mathrm{C}$ fits well with the findings from previous studies, suggesting that the accumulation of lacustrine sediments, drainage of thermokarst lakes, and accumulation of soils and organic layers in the basins occurred mostly during the Holocene (Kaplina, 2009; Grosse et al., 2013; Walter Anthony et al., 2014). Based on the radiocarbon dates and the cumulative SOC storages, the accumulation rates for the soil cores were calculated. The mean (linear) $\mathrm{C}$ accumulation rate of SOB14-T2-5 with $49.7 \mathrm{~g} \mathrm{C} \mathrm{m}^{-2} \mathrm{yr}^{-1}$ is very high, even higher than what has been found by Jones et al. (2012) for palaeo peat accumulation rates (9-35.2 $\left.\mathrm{g} \mathrm{C} \mathrm{m}^{-2} \mathrm{yr}^{-1}\right)$ in thermokarst basins on the Seward Peninsula. Nevertheless, it has to be considered that this site location is close to the Lena River with only approximately $5 \mathrm{~m}$ above river water level. It is likely that this location is affected by spring flood events which can deposit large amounts of sediments. On the other side, the site SOB14-T1-5 with $2.7 \mathrm{~g} \mathrm{C} \mathrm{m}^{-2} \mathrm{yr}^{-1}$ has very low accumulation rates and is most certainly not affected by the Lena River flood. For comparison, Kurganova et al. (2014) find that modern $\mathrm{C}$ accumulation on arable land in Russia was on average $9.6 \mathrm{~g} \mathrm{C} \mathrm{m}^{-2} \mathrm{yr}^{-1}$ over a 20-year period after abandonment. Hicks Pries et al. (2012) found a mean Holocene $\mathrm{C}$ accumulation rate of $25.8 \mathrm{~g} \mathrm{C} \mathrm{m}^{-2} \mathrm{yr}^{-1}$ for surface soils and $2.3 \mathrm{~g} \mathrm{C} \mathrm{m}^{-2} \mathrm{yr}^{-1}$ for deep soils in subarctic tundra in central Alaska. Bockheim et al. (2004) found a mean long-term accumulation rate of $13 \mathrm{~g} \mathrm{C} \mathrm{m}^{-2} \mathrm{yr}^{-1}$ for the last 5500 years in DTLBs in Arctic Alaska, but referring to the organic layer only.

Sediment accumulation rates are all of the same order of magnitude, excluding SOB14-T2-5, which might be affected by the Lena River, with mean accumulation rates for the different thermokarst cores ranging between 0.13 and $0.26 \mathrm{~mm} \mathrm{yr}^{-1}$ and mean accumulation rates for yedoma up- land cores between 0.10 and $0.57 \mathrm{~mm} \mathrm{yr}^{-1}$ (Table 4). For comparison, Murton et al. (2015) found sediment accumulation rates between 0.75 and $2.00 \mathrm{~mm} \mathrm{yr}^{-1}$ for yedoma silt at Duvanny Yar in the Kolyma Lowland. However, these rates refer to a time period between 38700 and 23600 years BP. Also, Schirrmeister et al. (2002a, b) found a similar accumulation rate for a yedoma deposit (Mamontovy Khayata) on Bykovsky Peninsula of about $0.75 \mathrm{~mm} \mathrm{yr}^{-1}$ for the time period between 60000 and 6000 years BP. These rates are slightly higher than the rates calculated in our study. In addition, all presented sediment accumulation rates (Table 4) will be lower when taking into account the ice content within the deposits. Sediment accumulation rates corrected for soil core ice content are presented in the Table S6.

\subsection{Characterizing soil organic carbon}

The rather low $\mathrm{C} / \mathrm{N}$ ratio in our study is common to all sampled soils. Only individual samples showed higher $\mathrm{C} / \mathrm{N}$ ratios and in general there is a trend of decreasing $\mathrm{C} / \mathrm{N}$ ratios with increasing soil depth. Even though the permafrost organic matter is already partly degraded, these finding suggests that organic matter in the top permafrost layer may be remobilized and decomposed when thawed out as the result of fluctuation of the permafrost table due to climate change. Also, Strauss et al. (2015) found relatively small C / N ratios for yedoma and thermokarst samples (median values below 8 and 10), although they looked at samples from deeper deposits. The mean values from our study might be lower too when incorporating samples from greater depths; this is indicated by the decreasing $\mathrm{C} / \mathrm{N}$ ratio with increasing depth. Higher $\mathrm{C} / \mathrm{N}$ values in the upper metre of soil were found by Zubrzycki et al. (2013) with mean values between 20 and 42 from the Holocene river terrace and mean values between 13 and 21 for the active floodplain level of the Lena Delta. This indicates fresher material in these deposits compared to yedoma uplands and DTLB deposits.

\subsection{The fate of organic carbon in thermokarst-affected yedoma in Siberia}

Permafrost soil layers beneath the active layer and below $1 \mathrm{~m}$ depth are important for future $\mathrm{C}$ remobilization, because models suggest permafrost degradation and thaw well beyond $1 \mathrm{~m}$ depth by end of the $21 \mathrm{st}$ century (Lawrence et al., 2012; Koven et al., 2013). The cores and the high sam- 
ple resolution in this study provide detailed information on the $\mathrm{C}$ stored in the soil beneath the active layer in the study areas which will be thawed first by future warming. This study provides additional soil $\mathrm{C}$ and $\mathrm{N}$ data for multiple cores deeper than $100 \mathrm{~cm}$ for thermokarst-affected yedoma landscapes. Studies with such deep cores are rare and even the NCSCD contains three times more profiles for the 0 $100 \mathrm{~cm}$ (1778 profiles) interval than for estimations exceeding $100 \mathrm{~cm}$ depth (Hugelius et al., 2014).

Our upscaling suggests that the study sites contain significantly more $\mathrm{C}$ than soils in temperate climate zones (e.g. Wiesmeier et al., 2012). Both study areas could become sources of organic $\mathrm{C}$ and $\mathrm{N}$ if permafrost thaw continues in a warming Arctic. An estimation based on the sampled cores and the landform classification shows that with an overall deepening of the active layer of $10 \mathrm{~cm} 700000 \mathrm{t} \mathrm{C}$ $\left(1.6 \mathrm{~kg} \mathrm{C} \mathrm{m}^{-2}\right)$ will thaw out in both study areas combined (Table 5). A regional study of Siberian permafrost dynamics (Sazonova et al., 2004) includes scenarios where the active layer deepens by more than $100 \mathrm{~cm}$ in north-eastern Siberia at the end of the 21 st century. This would result in an additional pool of available SOC of $5830000 \mathrm{t}\left(13.2 \mathrm{~kg} \mathrm{C} \mathrm{m}^{-2}\right)$ in the two study areas combined. In addition, different forms of permafrost thaw other than active layer deepening would further increase the amounts of SOC thawed and mobilized. For example, lake shore erosion rapidly degrades permafrost around lakes and releases organic $\mathrm{C}$ to the aquatic environment. Shore erosion not only affects the active layer soils from the top but does affect deeper permafrost soil layers (Walter Anthony et al., 2016). This vulnerability of large currently frozen $\mathrm{C}$ pools to thaw highlights the importance of deep permafrost organic $\mathrm{C}$ to be considered in future $\mathrm{C}$ cycle models.

\section{Conclusions}

This study presents the first SOC and N inventories for SoboSise Island and Bykovsky Peninsula, two yedoma-dominated and thermokarst-affected landscapes in the north of eastern Siberia for the first $2 \mathrm{~m}$ of soil. These ice-rich permafrost landscapes are vulnerable to climate warming and have the potential to release large amounts of SOC and total $\mathrm{N}$ through active layer deepening and permafrost thaw.

Sampling sites in DTLBs were found to contain less organic $\mathrm{C}$ than soils in the yedoma upland. Permafrost soils in DTLBs were all of Holocene age and soils in the upper $2 \mathrm{~m}$ on the yedoma uplands largely were all part of a Holocene cover layer above late Pleistocene yedoma deposits. The mean upscaled landscape SOC storage for $0-100 \mathrm{~cm}$ is $20.2 \pm 2.9 \mathrm{~kg} \mathrm{C} \mathrm{m}^{-2}$ for Sobo-Sise and $25.9 \pm 9.3 \mathrm{~kg} \mathrm{C} \mathrm{m}^{-2}$ for Bykovsky Peninsula, which results in a total storage of 9.8 Tg C across both study areas for the first metre of soil. Based on our high sample density, detailed $\mathrm{C}$ estimations for active layer deepening were derived, suggesting that $5.8 \mathrm{Tg}$ $\left(13.2 \mathrm{~kg} \mathrm{C} \mathrm{m}^{-2}\right)$ of SOC may become available for microbial degradation due to thaw if the active layer deepens by $100 \mathrm{~cm}$ in the two study areas. The $\mathrm{N}$ stocks are an order of magnitude lower; nevertheless a mean of $1.8 \pm 0.2 \mathrm{~kg} \mathrm{~N} \mathrm{~m}^{-2}$ is stored on Sobo-Sise and $2.2 \pm 0.5 \mathrm{~kg} \mathrm{~N} \mathrm{~m}^{-2}$ on Bykovsky Peninsula for the $0-100 \mathrm{~cm}$ depth interval. Therefore, as a consequence of permafrost thaw not only SOC but also additional $\mathrm{N}$ may become available for plants and microorganisms.

This study confirms the importance of yedoma and thermokarst landscapes for the permafrost $\mathrm{C}$ pool and adds important shallow and deep $\mathrm{C}$ and $\mathrm{N}$ data to the permafrost region soil databases. It also shows the high variability of SOC and $\mathrm{N}$ distribution in thermokarst-affected yedoma environments. Our study particularly underlines the benefits of soil cores beyond $1 \mathrm{~m}$ depth when capturing the high variability both within the soil and the entire landscape. Our result on $\mathrm{C}$ and $\mathrm{N}$ storage and availability to permafrost thaw in the upper subsurface points towards the fact that not only does the amount of $\mathrm{C}$ and $\mathrm{N}$ require more attention in the yedoma region but so does the potential for remobilization and the fate of freshly thawed organic matter. Even though Sobo-Sise Island and the Bykovsky Peninsula do not contain extraordinarily high SOC stocks in the near-surface permafrost at soil profile level, they nevertheless have a large potential for rapid mobilization of significant amounts of $\mathrm{C}$ due to their large proportion of thaw-vulnerable juvenile yedoma and thermokarst-affected landscape units.

Data availability. The data in this article are available at: https://doi.org/10.1594/PANGAEA.883582 (Fuchs et al., 2017).

\section{The Supplement related to this article is available online at https://doi.org/10.5194/bg-15-953-2018-supplement.}

Author contributions. MF designed the study; MF, GG, JS, FG, MG, GMM conducted the field work during the expedition Lena 2014; MF carried out the laboratory analysis; FG generated the high-resolution DEMs; and MF wrote the publication with input from all co-authors.

Competing interests. The authors declare that they have no conflict of interest.

Acknowledgements. This study was supported by ERC Starting Grant no. 338335 and the Initiative and Networking Fund of the Helmholtz Association (no. ERC-0013). We thank Thomas Opel and Ingmar Nitze for help with coring on Sobo-Sise Island and Bykovsky Peninsula during the expedition Lena Delta 2014, and Suzanne Jock, Theresa Henning and Dyke Scheidemann for help 
with the laboratory work. RapidEye imagery was kindly provided by the German Aerospace Center (DLR) and BlackBridge AG through the RapidEye Science Archive. The authors thank the editor and three anonymous reviewers for their constructive comments.

Edited by: Elise Pendall

Reviewed by: three anonymous referees

\section{References}

Abbott, B. W., Jones, J. B., Schuur, E. A. G., Chapin III, F. S., Bowden, W. B., Bret-Harte, M. S., Epstein, H. E., Flannigan, M. D., Harms, T. K., Hollingsworth, T. N., Mack, M. C., McGuire, A. D., Natali, S. M., Rocha, A. V., Tank, S. E., Turetsky, M. R., Vonk, J. E., Wickland, K. P., Aiken, G. R., Alexander, H. D., Amon, R. M. W., Benscoter, B. W., Bergeron, Y., Bishop, K., Blarquez, O., Bond-Lamberty, B., Breen, A. L., Buffam, I., Cai, Y., Carcaillet, C., Carey, S. K., Chen, J. M., Chen, H. Y. H., Christensen, T. R., Cooper, L. W., Cornelissen, J. H. C., de Groot, W. J., DeLuca, T. H., Dorrepaal, E., Fetcher, N., Finlay, J. C., Forbes, B. C., French, N. H. F., Gauthier, S., Girardin, M. P., Goetz, S. J., Goldammer, J. G., Gough, L., Grogan, P., Guo, L., Higuera, P. E., Hinzman, L., Hu, F. S., Hugelius, G., Jafarov, E. E., Jandt, R., Johnstone, J. F., Karlsson, J., Kasischke, E. S., Kattner, G., Kelly, R., Keuper, F., Kling, G. W., Kortelainen, P., Kouki, J., Kuhry, P., Laudon, H., Laurion, I., Macdonald, R. W., Mann, P. J., Martikainen, P. J., McClelland, J. W., Molau, U., Oberbauer, S. F., Olefeldt, D., Paré, D., Parisien, M.-A., Payette, S., Peng, C., Pokrovsky, O. S., Rastetter, E. B., Raymond, P. A., Raynolds, M. K., Rein, G., Reynolds, J. F., Robard, M., Rogers, B. M., Schädel, C., Schaefer, K., Schmidt, I. K., Shvidenko, A., Sky, J., Spencer, R. G. M., Starr, G., Striegl, R. G., Teisserenc, R., Tranvik, L. J., Virtanen, T., Welker, J. M., and Zimov, S.: Biomass offsets little or none of permafrost carbon release from soils, streams, and wildfire: an expert assessment, Environ. Res. Lett., 11, 34014, https://doi.org/10.1088/1748-9326/11/3/034014, 2016.

Beermann, F., Teltewskoi, A., Fiencke, C., Pfeiffer, E.-M., and Kutzbach, L.: Stoichiometric analysis of nutrient availability (N, $\mathrm{P}, \mathrm{K})$ within soils of polygonal tundra, Biogeochemistry, 122, 211-227, https://doi.org/10.1007/s10533-014-0037-4, 2015.

Bockheim, J. G., Hinkel, K. M., Eisner, W. R., and Dai, X. Y.: Carbon pools and accumulation rates in an age-series of soil in drained thaw-lake basins, Arctic Alaska, Soil Sci. Soc. Am. J., 68, 697-704, 2004.

Boike, J., Kattenstroth, B., Abramova, K., Bornemann, N., Chetverova, A., Fedorova, I., Fröb, K., Grigoriev, M., Grüber, M., Kutzbach, L., Langer, M., Minke, M., Muster, S., Piel, K., Pfeiffer, E.-M., Stoof, G., Westermann, S., Wischnewski, K., Wille, C., and Hubberten, H.-W.: Baseline characteristics of climate, permafrost and land cover from a new permafrost observatory in the Lena River Delta, Siberia (1998-2011), Biogeosciences, 10, 2105-2128, https://doi.org/10.5194/bg-10-21052013, 2013.

Brown, J., Ferrians Jr., J. O., Heginbottom, J. A., and Melnikov, E. S.: Circum-Arctic map of permafrost and ground-ice conditions, $1: 10000$ 000, Map CP-45, United States Geological Survey, International Permafrost Association, 1997.
Dutta, K., Schuur, E. A. G., Neff, J. C., and Zimov, S. A.: Potential carbon release from permafrost soils of Northeastern Siberia, Glob. Change Biol., 12, 2336-2351, https://doi.org/10.1111/j.1365-2486.2006.01259.x, 2006.

Chapin III, F. S., Shaver, G. R., Giblin, A. E., Nadelhoffer, K. J., and Laundre, J. A.: Responses of Arctic tundra to experimental and observed changes in climate, Ecology, 76, 694-711, 1995.

French, H. and Shur, Y.: The principles of cryostratigraphy, Earth-Sci. Rev., 101, 190-206, https://doi.org/10.1016/j.earscirev.2010.04.002, 2010.

Fuchs, M., Kuhry, P., and Hugelius, G.: Low below-ground organic carbon storage in a subarctic Alpine permafrost environment, The Cryosphere, 9, 427-438, https://doi.org/10.5194/tc-9-4272015, 2015.

Fuchs, M., Grosse, G., Strauss, J., Günther, F., Grigoriev, M. N., Maximov, G. M., and Hugelius, G.: Sample site characteristics including mean SOC and SN for permafrost cores collected on Sobo-Sise Island and Bykovsky Peninsula, PANGAEA, https:// doi.org/10.1594/PANGAEA.883582, 2017.

Goslar, T., Czernik, J., and Goslar, E.: Low-energy ${ }^{14} \mathrm{C}$ AMS in Poznan Radiocarbon Laboratory, Poland, Nucl. Instrum. Methods B, 223/224, 5-11, https://doi.org/10.1016/j.nimb.2004.04.005, 2004.

Grigoriev, M. N.: Cryomorphogenesis in the Lena Delta, Permafrost Institute Press, Yakutsk, 176 pp., 1993 (in Russian).

Grigoriev, M. N., Imaev, V. S., Imaeva, L. P., Kozmin, B. M., Kunitsky, V. V., Larionov, A. G., Mikulenko, K. L., Skrjabin, R. M., and Timirsin, K. V.: Geology, seismicity and cryogenic processes in the Arctic areas of western Yakutia, Yakutsk: Yakut Scientific Center, Siberian Branch, Russian Academy of Sciences, 1996 (in Russian).

Grigoriev, M. N.: Shore erosion studies on the Ice Complex Islands in the South-East Lena Delta, in: Russian-German Cooperation System Laptev Sea: The Expedition LENA 2006, edited by: Boike, J., Bolyshiyanov, D. Y., and Grigoriev, M. N., Reports on Polar and Marine Research, 566, 9-15, 2007.

Grosse, G., Schirrmeister, L., Kunitsky, V., and Hubberten H.-W.: The use of CORONA images in remote sensing of periglacial geomorphology: An illustration from the NE Siberian Coast, Permafrost Periglac., 16, 163-172, https://doi.org/10.1002/ppp.509, 2005.

Grosse, G., Schirrmeister, L., and Malthus, T. J.: Application of Landsat-7 satellite data and a DEM for the quantification of thermokarst-affected terrain types in the periglacial Lena-Anabar coastal lowland, Polar Res., 25, 51-67, 2006.

Grosse, G., Schirrmeister L., Siegert, C., Kunitsky, V. V., Slagoda, E. A., Andreev, A. A., and Dereviagyn, A. Y.: Geological and geomorphological evolution of a sedimentary periglacial landscape in Northeast Siberia during the Late Quaternary, Geomorphology, 86, 25-51, https://doi.org/10.1016/j.geomorph.2006.08.005, 2007.

Grosse, G., Jones, B., and Arp, C.: Thermokarst lakes, drainage, and drained basins, in: Treatise on Geomorphology, edited by: Shroder, J. F., Giardino, R., and Harbor, J., Vol. 8, Glacial and Periglacial Geomorphology, San Diego, Academic Press, 325353, 2013.

Gruber, N., Friedlingstein, P., Field, C. B., Valentini, R., Heimann, M., Richey, J. E., Romero Lankao, P., Schulze, E.-D., and Chen, C.-T. A.: The vulnerability of the carbon cycle in the $21 \mathrm{st}$ 
Century: An assessment of carbon-climate-human interactions, in: The Global Carbon Cycle: Integrating Humans, Climate and the Natural World, edited by: Field, C. and Raupach, M., Island Press, Washington DC, USA, 45-76, 2004.

Günther, F., Overduin, P. P., Yakshina, I. A., Opel, T., Baranskaya, A. V., and Grigoriev, M. N.: Observing Muostakh disappear: permafrost thaw subsidence and erosion of a ground-ice-rich island in response to arctic summer warming and sea ice reduction, The Cryosphere, 9, 151-178, https://doi.org/10.5194/tc-9-151-2015, 2015.

Harden, J. W., Koven, C. D., Ping, C.-L., Hugelius, G., McGuire, A. D., Camill, P., Jorgenson, T., Kuhry, P., Michaelson, G. J., O’Donnel, J. A., Schuur, E. A. G., Tarnocai, C., Johnson, K., and Grosse, G.: Field information links permafrost carbon to physical vulnerabilities of thawing, Geophys. Res. Lett., 39, L15704, https://doi.org/10.1029/2012GL051958, 2012.

Hicks Pries, C. E., Schuur, E. A. G., and Crummer, K. G.: Holocene carbon stocks and carbon accumulation rates altered in soils undergoing permafrost thaw, Ecosystems, 15, 162-173, https://doi.org/10.1007/s10021-011-9500-4, 2012.

Hinkel, K. M., Eisner, W. R., Bockheim, J. G., Nelson, F. E., Peterson, K. M., and Dai, X.: Spatial extent, age and carbon stocks in DTLBs on the Barrow Peninsula, Alaska, Arct. Antarct. Alp. Res., 35, 291-300, 2003.

Horwath Burnham, J. and Sletten, R. S.: Spatial distribution of soil organic carbon in northwest Greenland and underestimates of high arctic carbon stores, Global Biogeochem. Cy., 24, GB3012, https://doi.org/10.1029/2009GB003660, 2010.

Hugelius, G.: Spatial upscaling using thematic maps: An analysis of uncertainties in permafrost soil carbon estimates, Global Biogeochem. Cy., 26, GB2026, https://doi.org/10.1029/2011GB004154, 2012.

Hugelius, G. and Kuhry, P.: Landscape partitioning and environmental gradient analyses of soil organic carbon in a permafrost environment, Global Biogeochem. Cy., 23, GB3006, https://doi.org/10.1029/2008GB003419, 2009.

Hugelius, G., Kuhry, P., Tarnocai, C., and Virtanen, T.: Soil organic carbon pools in a periglacial landscape: a case study from the Central Canadian Arctic, Permafrost Periglac., 21, 16-29, https://doi.org/10.1002/ppp.677, 2010.

Hugelius, G., Virtanen, T., Kaverin, D., Pastukhov, A., Rivkin, F., Marchenko, S., Romanovsky, V., and Kuhry, P.: Highresolution mapping of ecosystem carbon storage and potential effects of permafrost thaw in periglacial terrain, European Russian Arctic, J. Geophys. Res., 116, G03024, https://doi.org/10.1029/2010JG001606, 2011.

Hugelius, G., Routh, J., Kuhry, P., and Crill, P.: Mapping the degree of decomposition and thaw remobilization potential of soil organic matter in discontinuous permafrost terrain, J. Geophys. Res., 117, G02030, https://doi.org/10.1029/2011JG001873, 2012.

Hugelius, G., Strauss, J., Zubrzycki, S., Harden, J. W., Schuur, E. A. G., Ping, C.-L., Schirrmeister, L., Grosse, G., Michaelson, G. J., Koven, C. D., O’Donnell, J. A., Elberling, B., Mishra, U., Camill, P., Yu, Z., Palmtag, J., and Kuhry, P.: Estimated stocks of circumpolar permafrost carbon with quantified uncertainty ranges and identified data gaps, Biogeosciences, 11, 6573-6593, https://doi.org/10.5194/bg-11-6573-2014, 2014.
Hugelius, G., Kuhry, P., and Tarnocai, C.: Ideas and perspectives: Holocene thermokarst sediments of the Yedoma permafrost region do not increase the northern peatland carbon pool, Biogeosciences, 13, 2003-2010, https://doi.org/10.5194/bg-13-20032016, 2016.

Jones, M. C., Grosse, G., Jones, B. M., and Walter Anthony, K.: Peat accumulation in drained thermokarst lake basins in continuous, ice-rich permafrost, northern Seward Peninsula, Alaska, J. Geophys. Res., 117, G00M07, https://doi.org/10.1029/2011JG001766, 2012.

Jorgenson, M. T.: Hierarchical organization of ecosystems at multiple spatial scales on the Yukon-Kuskokwim Delta, Alaska, USA, Arct. Antarct. Alp. Res., 32, 221-239, 2000.

Jorgenson, M. T. and Shur, Y.: Evolution of lakes and basins in northern Alaska and discussion of the thaw lake cycle, J. Geophys. Res., 112, F02S17, https://doi.org/10.1029/2006JF000531, 2007.

Kaplina, T. N.: Alas complex of Northern Yakutia, Kriosfera Zemli (Earth Crysophere), 13, 3-17, 2009 (in Russian).

Kanevskiy, M., Shur, Y., Jorgenson, M. T., Ping, C.-L., Michaelson, G. J., Fortier, D., Stephani, E., Dillon, T., and Tumskoy, V.: Ground ice of the upper permafrost of the Beaufort Sea coast of Alaska, Cold Reg. Sci. Technol., 85, 56-70, https://doi.org/10.1016/j.coldregions.2012.08.002, 2013.

Kanevskiy, M., Jorgenson, T., Shur, Y., O’Donnel, J. A., Harden, J. W., Zhuang, Q., and Fortier, D.: Cryostratigraphy and permafrost evolution in the lacustrine lowlands of West-Central Alaska, Permafrost Periglac., 25, 14-34, https://doi.org/10.1002/ppp.1800, 2014.

Keuper, F., van Bodegom, P. M., Dorrepaal, E., Weedon, J. T., van Hal, J., van Logtestijn, R. S. P., and Aerts, R.: A frozen feast: thawing permafrost increases plant-available nitrogen in subarctic peatlands, Glob. Change Biol., 18, 1998-2007, https://doi.org/10.1111/j.1365-2486.2012.02663.x, 2012.

Keuper, F., Dorrepaal, E., van Bodegom, P. M., van Logtestijn, R., Venhuizen, G., van Hal, J., and Aerts, R.: Experimentally increased nutrient availability at the permafrost thaw front selectively enhances biomass production of deep-rooting subarctic peatland species, Glob. Change Biol., 23, 4257-4266, https://doi.org/10.1111/gcb.13804, 2017.

Kholodov, A. L., Zolotarea, B. N., and Shirshova, L. T.: Organic matter in the main types of frozen quaternary deposits of the Bykovsky Peninsula: Total content and group composition of the Humus, Earth's Cryosphere, 10, 29-34, 2006 (in Russian).

Kokelj, S. V. and Jorgenson, M. T.: Advances in thermokarst research, Permafrost Periglac., 24, 108-109, https://doi.org/10.1002/ppp.1779, 2013.

Koven, C. D., Riley, W. J., and Stern, A.: Analysis of permafrost thermal dynamics and response to climate change in the CMIP5 Earth System Models, J. Clim., 26, 1877-1900, https://doi.org/10.1175/JCLI-D-12-00228.1, 2013.

Koven, C. D., Lawrence, D. M., and Riley, W. J.: Permafrost carbonclimate feedback is sensitive to deep soil carbon decomposability but not deep soil nitrogen dynamics, P. Natl. Acad. Sci. USA, 112, 3752-3757, https://doi.org/10.1073/pnas.1415123112, 2015.

Kuhry, P. and Vitt, D. H.: Fossil carbon/nitrogen ratios as a measure of peat decomposition, Ecology, 77, 271-275, 1996. 
Kuhry, P., Mazhitova, G. G., Forest, P.-A., Deneva, S. V., Virtanen, T., and Kultti, S.: Upscaling soil organic carbon estimates for the Usa Basin (Northeast European Russia) using GIS-based landcover and soil classification schemes, Dan. J. Geogr., 102, 11-25, 2002.

Kunitsky, V. B.: Cryolithogenesis of the lower Lena Permafrost, Inst. Acad. of Sci. USSR, Siberian Department Yakutsk, 1-162, 1989 (in Russian).

Kurganova, I., Lopes de Gerenyu, V., Six, J., and Kuzyakov, Y.: Carbon cost of collective farming collapse in Russia, Glob. Change Biol., 20, 938-947, https://doi.org/10.1111/gcb.12379, 2014.

Lantuit, H., Atkinson, D., Overduin, P. P., Grigoriev, M., Rachold, V., Grosse, G., and Hubberten, H.-W.: Coastal erosion dynamics on the permafrost-dominated Bykovsky Peninsula, north Siberia, 1951-2006, Polar Res., 30, 7341, https://doi.org/10.3402/polar.v30i0.7341, 2011.

Lawrence, D. M., Slater, A. G., and Swenson, S. C.: Simulation of present-day and future permafrost and seasonally frozen ground conditions in CCSM4, J. Clim., 25, 2207-2225, https://doi.org/10.1175/jcli-d-11-00334.1, 2012.

Mack, M. C., Schuur, E. A. G., Bret-Harte, M. S., Shaver, G. R., and Chapin III, F. S.: Ecosystem carbon storage in arctic tundra reduced by long-term nutrient fertilization, Nature, 431, 440-443, 2004.

Meyer, H., Dereviagin, A. Y., Siegert, C., and Hubberten, H.-W.: Paleoclimate studies on Bykovsky Peninsula, North Siberia - hydrogen and oxygen isotopes in ground ice, Polarforschung, 70, 37-51, 2002.

Michaelson, G. J., Ping, C. L., and Kimble J. M.: Carbon storage and distribution in tundra soils of Arctic Alaska, USA, Arctic Alpine Res., 28, 414-424, 1996.

Michaelson, G. J., Ping, C.-L., and Clark, M.: Soil pedon carbon and nitrogen data for Alaska: An analysis and update, Open J. Soil Sci., 3, 132-142, https://doi.org/10.4236/ojss.2013.32015, 2013.

Morgenstern, A., Grosse, G., Günther, F., Fedorova, I., and Schirrmeister, L.: Spatial analyses of thermokarst lakes and basins in Yedoma landscapes of the Lena Delta, The Cryosphere, 5, 849-867, https://doi.org/10.5194/tc-5-849-2011, 2011.

Morgenstern, A., Ulrich, M., Günther, F., Roessler, S., Fedorova, I. V., Rudaya, N. A., Wetterich, S., Boike, J., and Schirrmeister, L.: Evolution of thermokarst in East Siberian icerich permafrost: A case study, Geomorphology, 201, 363-379, https://doi.org/10.1016/j.geomorph.2013.07.011, 2013.

Murton, J. B., Goslar, T., Edwards, M. E., Bateman, M. D., Danilov, P. P., Savvinov, G. N., Gubin, S. V., Ghaleb, B., Haile, J., Kanevskiy, M., Lozhkin, A. V., Lupachev, A. V., Murton, D. K., Shur, Y., Tikhonov, A., Vasilchuk, A. C., Vasilchuk, Y. K., and Wolfe, S. A.: Palaeoenvironmental interpretation of Yedoma silt (Ice Complex) deposition as cold-climate loess, Duvanny Yar, Northeast Siberia, Permafrost Periglac., 26, 208-288, https://doi.org/10.1002/ppp.1843, 2015.

Natali, S. M., Schuur, E. A. G., and Rubin, R.: Increased plant productivity in Alaskan tundra as a result of experimental warming of soil and permafrost, J. Ecol., 100, 488-498, https://doi.org/10.1111/j.1365-2745.2011.01925.x, 2012.

Nitze, I. and Grosse, G.: Detection of landscape dynamics in the Arctic Lena Delta with temporally dense Landsat time-series stacks, Remote Sens. Environ., 181, 27-41, https://doi.org/10.1016/j.rse.2016.03.038, 2016.
Nowinski, N. S., Trumbore, S. E., Schuur, E. A. G., Mack, M. C., and Shaver, G. R.: Nutrient addition prompts rapid destabilization of organic matter in an Arctic tundra ecosystem, Ecosystems, 11, 16-25, https://doi.org/10.1007/s10021007-9104-1, 2008.

Obu, J., Lantuit, H., Myers-Smith, I., Heim, B., Wolter, J., and Fritz, M.: Effect of terrain characteristics on soil organic carbon and total nitrogen stocks in soils of Herschel Island, Western Canadian Arctic, Permafrost Periglac., 28, 92-107, https://doi.org/10.1002/ppp.1881, 2017.

Olefeldt, D., Goswami, S., Grosse, G., Hayes, D., Hugelius, G., Kuhry, P., McGuire, A. D., Romanovsky, V. E., Sannel, A. B. K., Schuur, E. A. G., and Turetsky, M. R.: Circumpolar distribution and carbon storage of thermokarst landscapes, Nat. Commun., 7, 13043, https://doi.org/10.1038/ncomms13043, 2016.

Palmtag, J., Hugelius, G., Lashchinskiy, N., Tamstorf, M. P., Richter, A., Elberling B., and Kuhry, P.: Storage, landscape distribution, and burial history of soil organic matter in contrasting areas of continuous permafrost, Arct. Antarct. Alp. Res, 47, 7188, https://doi.org/10.1657/AAAR0014-027, 2015.

Palmtag, J., Ramage, J., Hugelius, G., Gentsch, N., Lashchinskiy, N., Richter, A., and Kuhry, P.: Controls on the storage of organic carbon in permafrost soil in northern Siberia, Eur. J. Soil Sci., 67, 478-491, https://doi.org/10.1111/ejss.12357, 2016.

Peel, M. C., Finlayson, B. L., and McMahon, T. A.: Updated world map of the Köppen-Geiger climate classification, Hydrol. Earth Syst. Sci., 11, 1633-1644, https://doi.org/10.5194/hess-11-16332007, 2007.

Ping, C. L., Michaelson, G. J., Jorgenson, M. T., Kimble, J. M., Epstein, H., Romanovsky, V. E., and Walker, D. A.: High stocks of soil organic carbon in the North American arctic region, Nat. Geosci., 1, 615-619, https://doi.org/10.1038/ngeo284, 2008.

Ping, C.-L., Michaelson, G. J., Guo, L., Jorgenson, M. T., Kanevskiy, M., Shur, Y., Dou, F., and Liang, J.: Soil carbon and material fluxes across the eroding Alaska Beaufort Sea coastline, J. Geophys. Res., 116, G02004, https://doi.org/10.1029/2010JG001588, 2011.

Salmon, V. G., Soucy, P., Mauritz, M., Celis, G., Natali, S. M., Mack, M. C., and Schuur, E. A. G.: Nitrogen availability increases in a tundra ecosystem during five years of experimental permafrost thaw, Glob. Change Biol., 22, 1927-1941, https://doi.org/10.1111/gcb.13204, 2016.

Santoro, M. and Strozzi, T.: Circumpolar digital elevation models $>55^{\circ} \mathrm{N}$ with links to geotiff images, ESA data user element permafrost, Pangaea, Data Publisher for Earth \& Environmental Science, https://doi.org/10.1594/PANGAEA.779748, 2012.

Sazonova , T. E., Romanovsky, V. E., Walsh, J. E., and Sergueev, D. O.: Permafrost dynamics in the 20th and 21st centuries along the East Siberian transect, J. Geophys. Res., 109, D01108, https://doi.org/10.1029/2003JD003680, 2004.

Schädel, C., Schuur, E. A. G., Bracho, R., Elberling, B., Knoblauch, C., Lee, H., Luo, Y., Shaver, G. R., and Turetsky, M. R.: Circumpolar assessment of permafrost $\mathrm{C}$ quality and its vulnerability over time using long-term incubation data, Glob. Change Biol., 20, 641-652, https://doi.org/10.1111/gcb.12417, 2014.

Schirrmeister, L., Siegert, C., Kuznetsova, T., Kuzmina, S., Andreev, A., Kienast, F., Meyer, H., and Bobrov, A.: Paleoenvironmental and paleoclimatic records from permafrost deposits in 
the Arctic region of Northern Siberia, Quatern. Int., 89, 97-118, 2002a.

Schirrmeister, L., Siegert, C., Kunitzky, V. V., Grootes, P. M., and Erlenkeuser, H.: Late Quaternary ice-rich permafrost sequences as a paleoenvironmental archive for the Laptev Sea Region in northern Siberia, Int. J. Earth Sci., 91, 154-167, https://doi.org/10.1007/s005310100205, 2002b.

Schirrmeister, L., Kunitsky, V., Grosse, G., Wetterich, S., Meyer, H., Schwamborn, G., Babiy, O., Derevyagin, A., and Siegert, C.: Sedimentary characteristics and origin of the Late Pleistocene Ice Complex on north-east Siberian Arctic coastal lowlands and islands - A review, Quatern. Int., 241, 3-25, https://doi.org/10.1016/j.quaint.2010.04.004, 2011a.

Schirrmeister, L., Grosse, G., Schnelle, M., Fuchs, M., Krbetschek, M., Ulrich, M., Kunitsky, V., Grigoriev, M., Andreev, A., Kienast, F., Meyer, H., Babiy, O., Klimova, I. Bobrov, A., Wetterich, S., and Schwamborn, G.: Late Quaternary paleoenvironmental records from the western Lena Delta, Arctic Siberia, Palaeogeogr. Palaeocl., 299, 175-196, https://doi.org/10.1016/j.palaeo.2010.10.045, 2011 b.

Schirrmeister, L., Grosse, G., Wetterich, S., Overduin, P. P., Strauss, J., Schuur, E. A. G., and Hubberten, H.-W.: Fossil organic matter characteristics in permafrost deposits of the northeast Siberian Arctic, J. Geophys. Res., 116, G00M02, https://doi.org/10.1029/2011JG001647, 2011c.

Schirrmeister, L., Froese, D., Tumskoy, V., Grosse, G., and Wetterich, S.: Yedoma: Late Pleistocene ice-rich syngenetic permafrost of Beringia, in: The Encyclopedia of Quaternary Science, edited by: Elias, S. A., Amsterdam, Elsevier, 3, 542-552, 2013.

Schneider, J., Grosse, G., and Wagner, D.: Land cover classification of tundra environments in the Arctic Lena Delta based on Landsat 7 ETM+ data and its application for upscaling of methane emissions, Remote Sens. Environ., 113, 380-391, https://doi.org/10.1016/j.rse.2008.10.013, 2009.

Schneider von Deimling, T., Grosse, G., Strauss, J., Schirrmeister, L., Morgenstern, A., Schaphoff, S., Meinshausen, M., and Boike, J.: Observation-based modelling of permafrost carbon fluxes with accounting for deep carbon deposits and thermokarst activity, Biogeosciences, 12, 3469-3488, https://doi.org/10.5194/bg12-3469-2015, 2015.

Schuur, E. A. G., Bockheim, J., Canadell, J. G., Euskirchen, E., Field, C. B., Goryachkin, S. V., Hagemann, S., Kuhry, P., Lafleur, P. M., Lee, H., Mazhitova, G., Nelson, F. E., Rinke, A., Romanovsky, V. E., Shiklomanov, N., Tarnocai, C., Venevsky, S., Vogel, J. G., and Zimov, S. A.: Vulnerability of permafrost carbon to climate change: Implications for the global carbon cycle, BioScience, 58, 701-714, https://doi.org/10.1641/B580807, 2008.

Schuur, E. A. G., McGuire, A. D., Schädel, C., Grosse, G., Harden, J. W., Hayes, D. J., Hugelius, G., Koven, C. D., Kuhry, P., Lawrence, D. M., Natali, S. M., Olefeldt, D., Romanovsky, V. E., Schaefer, K., Turetsky, M. R., Treat, C. C., and Vonk, J. E.: Climate change and the permafrost carbon feedback, Nature, 520, 171-179, https://doi.org/10.1038/nature14338, 2015.

Schwamborn, G., Rachold, V., and Grigoriev, M. N.: Late Quaternary sedimentation history of the Lena Delta, Quatern. Int., 89, 119-134, 2002.
Shaver, G. R., Chapin III, F., and Garnter, B. L.: Factors limiting seasonal growth and peak biomass accumulation in Eriophorum Vaginatum in Alaska tussock tundra, J. Ecol., 74, 257-278, 1986.

Shmelev, D., Veremeeva, A., Kraev, G., Kholodov, A., Spencer, R. G. M., Walker, W. S., and Rivkina, E.: Estimation and sensitivity of carobn storage in permafrost of North-Eastern Yakutia, Permafrost Periglac., 28, 379-390, https://doi.org/10.1002/ppp.1933, 2017.

Siegert, C., Schirrmeister, L., and Babiy, O.: The sedimentological, mineralogical and geochemichal composition of Late Pleistocene deposits from the Ice Complex on the Bykovsky Peninsula, Northern Siberia, Polarforschung, 70, 3-11, 2002.

Siewert, M. B., Hanisch, J., Weiss, N., Kuhry, P., Maximov, T. C., and Hugelius, G.: Comparing carbon storage of Siberian tundra and taiga permafrost ecosystems at very high spatial resolution, J. Geophys. Res.-Biogeo., 120, 1973-1994, https://doi.org/10.1002/2015JG002999, 2015.

Siewert, M. B., Hugelius, G., Heim, B., and Faucherre, S.: Landscape controls and vertical variability of soil carbon storage in permafrost-affected soils of the Lena River Delta, Catena 147, 725-741, https://doi.org/10.1016/j.catena.2016.07.048, 2016.

Slagoda, E. A.: Microstructure features of the deposits of ice complexes in northern Yakutia (by the example of Bykov Peninsula), in: Kriologiya pochv. Pushchino, edited by: Gilichinskiy D. A., IPFS PNTs AN SSSR, 38-47, 1991 (in Russian).

Slagoda, E. A.: Genesis and microstructure of cryolithogenic deposits at the Bykovsky Peninsula and the Muostakh Island, Dissertation, RAS Siberian Section, Permafrost Institute, Yakutsk, 1-218, 1993 (in Russian).

Soil Survey Staff: Keys to Soil Taxonomy, 12th Edn., United States Department of Agriculture \& Natural Resources Conservation Service, Washington, DC, 360 pp., 2014.

Strauss, J., Schirrmeister, L., Wetterich, S., Borchers, A., and Davydov, S. P.: Grain-size properties and organic-carbon stock of Yedoma Ice complex permafrost from the Kolyma lowland, northeastern Siberia, Global Biogeochem. Cy., 26, GB3003, https://doi.org/10.1029/2011GB004104, 2012.

Strauss, J., Schirrmeister, L., Grosse, G., Wetterich, S., Ulrich, M., Herzschuh, U., and Hubberten, H.-W.: The deep permafrost carbon pool of the Yedoma region in Siberia and Alaska, Geophys. Res. Lett., 40, 6165-6170, https://doi.org/10.1002/2013GL058088, 2013.

Strauss, J., Schirrmeister, L., Mangelsdorf, K., Eichhorn, L., Wetterich, S., and Herzschuh, U.: Organic-matter quality of deep permafrost carbon - a study from Arctic Siberia, Biogeosciences, 12, 2227-2245, https://doi.org/10.5194/bg-12-2227-2015, 2015.

Strauss, J., Schirrmeister, L., Grosse, G., Fortier, D., Hugelius, G., Knoblauch, C., Romanovsky, V., Schädel, C., Schneider von Deimling, T., Schuur, E. A. G., Shmelev, D., Ulrich, M., and Veremeeva, A.: Deep Yedoma permafrost: A synthesis of depositional characteristics and carbon vulnerability, Earth-Sci. Rev., 172, 75-86, https://doi.org/10.1016/j.earscirev.2017.07.007, 2017.

Stuiver, M. and Reimer, P. J.,: Extended ${ }^{14} \mathrm{C}$ data base and revised CALIB 3.0 ${ }^{14} \mathrm{C}$ age calibration program, Radiocarbon, 35, 215230, 1993.

Stuiver, M., Reimer, P. J., and Reimer, R. W.: CALIB 7.1 [WWW program], available at: http://calib.org, last access: 6 March 2017. 
Tarnocai, C.: The effect of climate change on carbon in Canadian peatlands, Global Planet. Change, 53, 222-232, https://doi.org/10.1016/j.gloplacha.2006.03.012, 2006.

Tarnocai, C., Canadell, J. G., Schuur, E. A. G., Kuhry, P., Mazhitova, G., and Zimov, S.: Soil organic carbon pools in the northern circumpolar permafrost region, Global Biogeochem. Cy., 23, GB2023, https://doi.org/10.1029/2008GB003327, 2009.

Ulrich, M., Grosse, G., Strauss, J., and Schirrmeister, L.: Quantifying wedge-ice volumes in Yedoma and thermokarst basin deposits, Permafrost Periglac., 25, 151-161, https://doi.org/10.1002/ppp.1810, 2014.

Veremeeva, A. A. and Glushkova, N. V.: Formation of relief in the regions of Ice Complex deposits distribution: remote sensing and GIS studies in the Kolyma lowland tundra, Earth's Cryosphere, 20, 14-24, 2016.

Veremeeva, A. and Gubin, S.: Modern tundra landscapes of the Kolyma Lowland and their evolution in the Holocene, Permafrost Periglac., 20, 399-406, https://doi.org/10.1002/ppp.674, 2009.

Walker, D. A., Raynolds, M. K., Daniëls, F. J. A., Einarsson, E., Elvebakk, A., Gould, W. A., Katenin, A. E., Kholod, S. S., Markonh, C. J., Melnikov, E. S., Moskalenko, N. G., Talbot, S. S., and Yurtsev, B. A.: The Circumpolar Arctic vegetation map, J. Veg. Sci., 16., 267-282, 2005.

Walter Anthony, K. M., Zimov, S. A., Grosse, G., Jones, M. C., Anthony, P. M., Chapin III, F. S., Finlay, J. C., Mack, M. C., Davydov, S., Frenzel, P., and Frolking S.: A shift of thermokarst lakes from carbon sources to sinks during the Holocene epoch, Nature, 511, 452-456, https://doi.org/10.1038/nature13560, 2014.

Walter Anthony, K. M., Daanen, R., Anthony, P., Schneider von Deimling, T., Ping, C.-L., Chanton, J. P., and Grosse, G.: Methane emissions proportional to permafrost carbon thawed in Arctic lakes since the 1950s, Nat. Geosci., 9, 679-682, https://doi.org/10.1038/NGEO2795, 2016.
Webb, E. E., Heard, K., Natali, S. M., Bunn, A. G., Alexander, H. D., Berner, L. T., Kholodov, A., Loranty, M. M., Schade, J. D., Spektor, V., and Zimov, N.: Variability in above- and belowground carbon stocks in a Siberian larch watershed, Biogeosciences, 14, 4279-4294, https://doi.org/10.5194/bg-14-42792017, 2017.

Weiss, N., Blok, D., Elberling, B., Hugelius, G., Juncher Jorgensen, C., Siewert, M. B., and Kuhry, P.: Thermokarst dynamics and soil organic matter characteristics controlling initial carbon release from permafrost soils in the Siberian Yedoma region, Sediment. Geol., 340, 38-48, https://doi.org/10.1016/j.sedgeo.2015.12.004, 2016.

Wiesmerier, M., Spörlein, P., Geuss, U., Hangen, E., Haug, S., Reischl, A., Schilling, B., von Lützow, M., and Kögel-Knaber, I.: Soil organic carbon stocks in southeast Germany (Bavaria) as affected by land use, soil type and sampling depth, Glob. Change Biol., 18, https://doi.org/10.1111/j.1365-2486.2012.02699.x, 2012.

Zimov, S. A., Davydov, S. P., Zimova, G. M., Davydova, A. I., Schuur, E. A. G., Dutta, K., and Chapin, F. S.: Permafrost carbon: Stock and decomposability of a globally significant carbon pool, Geophys. Res. Lett., 33, L20502, https://doi.org/10.1029/2006GL027484, 2006.

Zubrzycki, S., Kutzbach, L., Grosse, G., Desyatkin, A., and Pfeiffer, E.-M.: Organic carbon and total nitrogen stocks in soils of the Lena River Delta, Biogeosciences, 10, 3507-3524, https://doi.org/10.5194/bg-10-3507-2013, 2013. 